\title{
Towards Single Supervision and Resolution of Systemically Important Non-Bank Financial Institutions in the European Union
}

\author{
Danny Busch ${ }^{1,2,3,4,5}$ • Mirik B. J. van Rijn ${ }^{6}$
}

Published online: 28 March 2018

(C) The Author(s) 2018

\begin{abstract}
The global financial crisis proved that banks are not the sole source of systemic risk to the financial system and the wider economy. Indeed, systemic risk emanating from non-bank financial institutions proved to be a key vulnerability of the financial system. Such risks occurred, above all, when leveraged non-bank financial institutions performed bank-like activities such as maturity and/or liquidity transformation. However, the increasingly blurred distinction between markets, financial institutions, services and products is not matched in the European Union by an integrated regulatory and supervisory approach. Instead, regulation was and remains largely organised along sectoral lines, with an emphasis on the banking
\end{abstract}

\begin{abstract}
We completed this article on 1 August 2017 and have therefore been unable to take account of developments since that date. The article was prepared as part of the 2016 Legal Research Programme of the European Central Bank (ECB). We gratefully acknowledge the useful comments received during presentations of our proposals at the ECB on 31 May 2016, at the Annual Conference of the Journal of Financial Regulation in Hong Kong on 25 June 2016 and at the Institute for Financial Law of Radboud University Nijmegen on 2 September 2016. An earlier draft of this article benefited from anonymous review by the lawyers at the ECB and at the European Business Organization Law Review (EBOR). We also benefited from discussions with many others, including Arthur van den Hurk, Gerard Kastelein, Victor de Serière, Sander Timmerman and Rivka de Winter. All views expressed are the personal views of the authors.
\end{abstract}

Danny Busch

d.busch@jur.ru.nl

Mirik B. J. van Rijn

m.vanrijn@jur.ru.nl

1 Chair of Financial Law and Director of the Institute for Financial Law (IFL), Radboud University Nijmegen, Nijmegen, The Netherlands

2 Visiting Professor, Università degli Studi di Genova, Genoa, Italy

3 Visiting Professor, Università Cattolica del Sacro Cuore di Milano, Milan, Italy

4 Member of the Dutch Banking Disciplinary Committee (Tuchtcommissie Banken), Amsterdam, The Netherlands 
sector. As the global financial crisis shows, this creates a risk of gaps in the coverage of regulation and supervision, leading to inconsistent regulatory treatment of equivalent products and/or services. This in turn causes an unlevel playing field and increases the potential for regulatory arbitrage. In consequence, risky activities migrate to less regulated or unregulated parts of the financial system, leading to a largely unchecked build-up of systemic risk. Drawing inspiration from the reforms in the United States, we propose that the EU's system of financial regulation be complemented by a robust body charged with identifying and monitoring non-bank financial institutions that are systemically important. This EU authority should have the discretion to designate a non-bank financial institution as a Non-Bank Systemically Important Financial Institution (non-bank SIFI). A logical choice would be to confer such powers on the European Systemic Risk Board. Designated nonbank SIFIs should be placed under direct prudential supervision by an EU body. This EU supervisor would have to establish, on an individual or categorical basis, appropriate enhanced prudential requirements tailored to the nature, risks and activities of the relevant non-bank SIFI. Additionally, a single European resolution regime should be in place to ensure that non-bank SIFIs can fail without destabilising the financial system. This would avoid a possible 'Too-Big-To-Fail' status, remove implicit government guarantees and subject the institution to market discipline. Our proposal aims to ensure that non-bank SIFIs are brought within a regulatory perimeter and supervisory scrutiny consistent with the risk they pose to financial stability. Such a regime would (i) help to eliminate (national) supervisory and regulatory gaps, (ii) reduce regulatory arbitrage activities, and (iii) contribute to the stability of the financial system and a level playing field.

Keywords Supervision · Regulation - Resolution - Systemically important financial institutions · Non-bank SIFIs · Systemic risk · Regulatory arbitrage $\cdot$ Cross-sectoral

\section{Introduction}

In 2001 Roger Lowenstein noted that the Fed's initiative to organise a private bailout of hedge fund management firm Long-Term Capital Management (LTCM) was not done out of sympathy for LTCM nor to prevent losses to exposed financial

5 Member of the Appeal Committee of the Dutch Complaint Institute Financial Services (Klachteninstituut Financiële Dienstverlening, KiFiD), The Hague, The Netherlands

$6 \mathrm{PhD}$ Scholar and Junior Lecturer in Financial Law, Institute for Financial Law (IFL), Radboud University Nijmegen, Nijmegen, The Netherlands 
institutions. ${ }^{1}$ Instead, the driving concern was "the broader notion of "systemic risk"; if Long-Term failed, and if its creditors forced a hasty and disorderly liquidation, [the Fed] feared that it would harm the entire financial system, not just some of its big participants'. ${ }^{2}$ Still, with the last financial meltdown dating back to the 1930 s, it was unclear whether 'systemic risk' presented a real threat. Lowenstein noted that it was a 'parlor topic, not something the bankers wanted to spend $\$ 250$ million on'. 3

Any residual doubt about the threat posed by systemic risk was dispelled 10 years later when the onset of the Global Financial Crisis necessitated large-scale government intervention to prevent the markets from collapsing.

The Global Financial Crisis painfully demonstrated deficiencies in the regulation, supervision and resolution of financial institutions. Not only in the traditional banking sector but also in other parts of the financial system. Indeed, systemic risk manifested itself to a large degree outside the traditional banking sector, especially in the lightly regulated shadow banking sector. The latter refers, quite ominously, to market-based credit intermediation outside the banking sector. Due to a lack of comprehensive regulation and supervision, banks increasingly shifted activities to the shadow banking sector in order to avoid tax, disclosure and capital requirements. ${ }^{4}$ Such behaviour, which is designed to evade more stringent regulation and supervision or to evade regulation and supervision altogether, is known as regulatory arbitrage. The exploitation of regulatory gaps, however, creates risks to financial stability and puts paid to the notion of a level playing field.

To strengthen financial stability, we propose that non-bank financial institutions which are systemically relevant should be subjected to European prudential regulation and to a European supervisor and a European resolution authority. ${ }^{5}$

Our proposals exclude banks as they are already subject to stricter prudential regulation under the Capital Requirements Directives (CRD IV) and Capital Requirements Regulation (CRR) and, within the Member States participating in the European Banking Union (EBU), are subject to the Single Supervisory Mechanism (SSM) and the Single Resolution Mechanism (SRM). Within the SSM, significant banks are directly supervised by the ECB and resolved by the Single Resolution Board (SRB). ${ }^{6}$

In accordance with the approach of the Financial Stability Board ${ }^{7}$ and the US DoddFrank reforms, ${ }^{8}$ we advocate that the EU's sectoral approach to financial regulation,

\footnotetext{
${ }^{1}$ Lowenstein (2000), pp. 103-104.

${ }^{2}$ Lowenstein (2000), pp. 194-195.

3 Eventually, on 23 September 1998, a group of 14 financial institutions agreed to provide a capital injection of $\$ 3.625$ billion in return for a $90 \%$ share in the fund.

4 See, for example, Adrian et al. (2015), p. 392.

5 More broadly, it is also questionable whether a sectoral model of supervision is sufficient and indeed future-proof in the increasingly interconnected financial sector. See, for instance, Ferran (2015), p. 101; Awrey (2016). However, this article does not seek to revisit the make-up of the supervisory model in the EU as a whole but rather to supplement the existing framework with a robust holistic approach for the identification, supervision, regulation and resolution of non-bank SIFIs. Moreover, while our proposal concerns institution-based regulation and supervision this does not detract from the need for market and product-based regulation as essential complements to entity-based regulation.
}

6 As regards the European Banking Union, see for example Busch and Ferrarini (2015).

7 Financial Stability Board (2011b), para. 3. See infra Sect. 3.

812 US Code $\S 5323$. See infra Sect. 4. 
supervision and resolution be complemented by a more risk-based identification, regulation, supervision and resolution of non-bank systemically important financial institutions. Any non-bank financial institution ${ }^{9}$ which could pose a threat to financial stability_referred to as non-bank systemically important financial institutions (non-bank SIFIs)—should therefore be subject to commensurate supervision, regulation and resolution, regardless of the legal categorisation of the non-bank financial institution. ${ }^{10}$ This would entail partial reform and extension of supervision, regulation and resolution of financial institutions in the EU, which is presently organised largely along sectoral lines, and a move towards a more pan-sectoral regime for non-bank SIFIs. A cross-sectoral supervisory and resolution regime for non-bank SIFIs would correspond with the increasingly blurred distinction between markets, financial institutions and products. ${ }^{11}$ It would also help to reduce regulatory arbitrage activities and gaps in coverage, as it would ensure that the risks posed by a non-bank SIFI are subject to commensurate regulation, regardless of the legal form of the entity. In order to properly identify non-bank SIFIs, robust monitoring of the entire European financial sector is necessary.

The proposed regime is in line with financial reform proposals issued by the Financial Stability Board (FSB), which call for a level of supervision proportionate to the potential destabilisation risk that a financial firm poses to the financial system. ${ }^{12}$ Additionally, the FSB requires an effective resolution regime for all financial institutions which could be systemically significant or critical if they fail. ${ }^{13}$

For the development of such a regime we draw on the experiences in the US. There, non-bank financial companies can already be designated as systemically important. Such designation puts them under federal supervision and, reflecting their importance to the financial system, makes them subject to specific prudential and living will requirements. Additionally, non-bank financial institutions posing a systemic risk may be subjected to a specialised resolution regime.

This article seeks to contribute to the discussion on the development within the European Union of a regulatory regime which adequately addresses and mitigates the risk to financial stability posed by non-bank SIFIs. Section 2 therefore highlights the relevance of the problem by reiterating lessons learned from the Global Financial Crisis, especially in respect of the systemic risk posed by non-bank financial institutions. Section 3 examines recommendations made by international bodies, most notably the Financial Stability Board (FSB), in response to the Global Financial Crisis, to increase regulation, supervision and resolution in the financial sector. Section 4 draws inspiration from the US regime, which is of special interest as it already provides for the designation and consequential supervision and resolution of non-bank SIFIs. Section 5 considers the existing body of European financial regulation. We assess what has already been accomplished since the Global Financial Crisis and provide context to our proposed

\footnotetext{
9 'Financial institution' should be understood as a broad term encapsulating all financial sector entities.

10 The FSB defines SIFIs as 'financial institutions whose distress or disorderly failure, because of their size, complexity and systemic interconnectedness, would cause significant disruption to the wider financial system and economic activity'.

11 Ferran (2015) and Huang and Schoenmaker (2014).

12 Financial Stability Board (2013c), p. 18.

13 Financial Stability Board (2011a).
} 
regime of non-bank SIFI supervision and resolution. Section 6 makes suggestions and explores legal possibilities for enhancing the existing body of European financial regulation by including designation, supervision and resolution of non-bank SIFIs at the European level. Section 7 contains our concluding remarks.

\section{Systemic Risk}

The Global Financial Crisis highlighted a number of structural weaknesses in the worldwide financial system and economies. One of the most important lessons was the, generally unforeseen, possibility of systemic risk originating from non-bank financial institutions.

Systemic risk is the risk that a national, regional or the global, financial system will break down. ${ }^{14}$ Systemic risks manifest themselves where a localised shocksuch as the failure of a financial institution-has repercussions that adversely affect the broader economy. ${ }^{15}$ It thus poses a threat to financial stability. ${ }^{16}$ Systemic risk can manifest itself in many different forms and within a range of financial institutions. As noted by Anabtawi and Schwarcz, systemic risks do not distinguish between financial market participants. ${ }^{17}$ Systemic risk should therefore be regarded as an elusive concept, not confined to certain institutions, markets or products. ${ }^{18}$ Accordingly, financial regulation should have an equally flexible and open scope.

Despite the regulatory focus, it turned out that systemic risk was not confined to the (retail) banking sector. Non-bank financial institutions such as Long-Term Capital Management (LTCM), American International Group (AIG) and Reserve Primary proved equally capable of creating systemic risk. This realisation is reflected in the European Systemic Risk Board Regulation, which acknowledges that all types of financial intermediaries, markets and infrastructure may potentially be systemically important to some degree. ${ }^{19}$ Additionally, both the legislative proposal of the European Commission (Commission) on a framework for the recovery and resolution of central counterparties $(\mathrm{CCPs})^{20}$ and its proposal for the creation of a new supervisory

\footnotetext{
14 Scott (2010), p. 764.

15 Anabtawi and Schwarcz (2011) p. 1351. Schwarcz further defines systemic risk as 'the risk that (i) an economic shock such as market or institutional failure triggers (through a panic or otherwise) either (X) the failure of a chain of markets or institutions or (Y) a chain of significant losses to financial institutions, (ii) resulting in increases in the cost of capital or decreases in its availability, often evidenced by substantial financial-market price volatility.' See Schwarcz (2008), p. 203.

16 Lastra (2015), p. 312.

17 Anabtawi and Schwarcz (2011), fn. 10.

18 Indeed, the creation of suitable regulation of markets and financial products-for example by increasing market transparency and through product approval processes - is essential for the safeguarding of financial stability. However, this article focuses mainly on the regulation of entities, specifically nonbank SIFIs.

19 Regulation (EU) No. 1092/2010 on European Union macro-prudential oversight of the financial system and establishing a European Systemic Risk Board [2010] OJ L331 (ESRB Regulation), Art. 2 sub (c).

${ }^{20}$ Recognising the central and growing systemic importance of CCPs-resulting from the G20 commitment to clear additional classes of over-the-counter derivatives with CCPs-the European Commission proposed recovery and resolution measures to safeguard financial stability. See Proposal for
} 
mechanism for CCPs aim to regulate and supervise the systemic risk posed by CCPs. ${ }^{21}$ This illustrates our premise that non-bank financial institutions are equally capable of posing systemic risks. ${ }^{22}$ Asset management activities are another example of a potential source of non-bank systemic risk which has recently attracted attention. ${ }^{23}$

The Commission's proposal for the establishment of a Capital Markets Union (CMU) is also of interest as the envisaged growth of non-bank credit intermediation makes overarching checks on systemic risks even more pressing. ${ }^{24}$ Designed to increase the supply of alternative sources of financing - thereby reducing dependence on funding through the banking sector-the CMU proposal looks to increase the role of non-bank financial intermediaries. ${ }^{25}$ Such diversification of funding improves the allocation of capital and diversification of risk and thereby strengthens the European financial system. At the same time, as recognised by the 'Five Presidents' Report', closer integration of capital markets and gradual removal of remaining national barriers necessitates an expansion and strengthening of the available tools to manage financial players' systemic risks prudently (macro-prudential toolkit) and to strengthen the supervisory framework to ensure the solidity of all financial actors. ${ }^{26}$ This should, according to the report, ultimately lead to a single European capital markets supervisor. ${ }^{27}$

This shows that systemic risk can occur in different sectors, or indeed across different sectors, and have a variety of distinct characteristics. Therefore it might be difficult to identify such risks. It is therefore of great importance for jurisdictions to have a broad monitoring system in place, capable of identifying systemic risk throughout the entire financial sector.

\subsection{Deregulation and Growth of the Financial Sector}

As this article aims to contribute to the discussion on how to alleviate systemic risk, specifically in regard to non-bank financial institutions, a short consideration of the role of such entities in the manifestation of systemic risk, especially during the Global Financial Crisis, is in order.

\footnotetext{
Footnote 20 continued

a Regulation of the European Parliament and of the Council on a framework for the recovery and resolution of central counterparties and amending Regulations (EU) No. 1095/2010, (EU) No. 648/2012, and (EU) 2015/2365, COM(2016) 856 final.

21 See on the supervision of CCPs Sect. 5.2.2.

22 At the same time, CCPs have very specific market infrastructural functions which, in their case, might warrant a specific, sectoral, approach to their regulation and supervision. As our paper focuses on banklike risks occurring in non-bank financial institutions, CCPs fall outside the scope of our proposed regulatory reforms owing to their specific activities.

23 See Financial Stability Board (2017c); Doyle et al. (2016). The FSB found that the worldwide assets under management rose from $\$ 53.6$ trillion in 2005 to $\$ 76.7$ trillion in 2015 , equating to $40 \%$ of global financial system assets. It identified a number of potential financial stability risks in asset management activities. This is discussed in Sect. 3.1.

24 See also: Véron and Wolff (2016); Alexander (2015).

25 European Commission (2015b).

26 Juncker et al. (2015), p. 12.

27 Juncker et al. (2015), p. 12. See extensively on CMU: Busch et al. (2018a); Busch (2017).
} 
By the mid-1990s the financial sectors in the EU and US were thriving. Technological advances, for instance in information services, led to economy-ofscale benefits. ${ }^{28}$ Additionally, the perception that some of the largest financial institutions were Too-Big-To-Fail provided them with implicit guarantees, thereby generating additional confidence and growth. ${ }^{29}$

At the same time, financial institutions, notably banks, successfully advocated deregulation and the removal of obstacles to growth and competition. ${ }^{30}$ In 1994 this led the US to allow bank holding companies to acquire bank subsidiaries in all states. ${ }^{31}$ In 1999 this was followed by the Gramm-Leach-Bliley Act which repealed the restriction on affiliations between banks and securities firms imposed by the GlassSteagall Act. As a consequence, banks were allowed to underwrite and sell securities and insurance products. Conversely, it allowed securities firms and investment banks to take deposits. Such developments paved the way for large-scale consolidation and growth within and across the banking, securities and insurance sector. ${ }^{32}$ Boosted by progress in the creation of an internal market-specifically through the abolition of obstacles to the free flow of goods, persons, services and capital and the creation of the euro in 1999-a similar trend of increased cross-border activities, consolidation, and growth of financial institutions was evident in the European Union. ${ }^{33}$

The financial supervisory and regulatory regimes remained, however, highly fragmented both geographically and sectorally. In the US, competition between supervisors led to a race to the bottom and, in the absence of a robust consolidated supervisor, regulators failed to identify excessive risks and unsound practices in non-bank financial institutions. ${ }^{34}$ Securities firms, for example, were allowed to

\footnotetext{
${ }^{28}$ Financial Crisis Inquiry Commission (2011), p. 52.

29 See, for instance, Santos (2014); Brewer and Jagtiani (2013); Baker and McArthur (2009).

30 This led the US Financial Crisis Inquiry Commission to conclude that: 'More than 30 years of deregulation and reliance on self-regulation by financial institutions, championed by former Federal Reserve chairman Alan Greenspan and others, supported by successive administrations and Congresses, and actively pushed by the powerful financial industry at every turn, had stripped away key safeguards, which could have helped avoid catastrophe. This approach had opened up gaps in oversight of critical areas with trillions of dollars at risk, such as the shadow banking system and over-the-counter derivatives markets.' See Conclusions of the Financial Crisis Inquiry Commission (2011), p. xviii.

31 Achieved through the Riegle-Neal Interstate Banking and Branching Efficiency Act, which effectively repealed federally imposed geographical banking restrictions imposed by the McFadden Act of 1927.

32 'Between 1990 and 2005, 74 "megamergers" occurred involving banks with assets of more than \$10 billion each. Meanwhile the 10 largest jumped from owning $25 \%$ of the industry's assets to $50 \%$ '. See Financial Crisis Inquiry Commission (2011), pp. 52-53.

33 See inter alia: Eichengreen (2015), chapter 6; Wolf (2014).

34 US investment banks, for instance, were free to choose their consolidated regulator. All five major US investment banks opted for supervision under the Consolidated Supervised Entity program of the Securities and Exchange Commission (SEC). In turn, the SEC applied light capital requirements and never assigned on-site examiners. In a 2008 report the Fed noted that the biggest problem investment banks had with structuring in a way that they would be supervised by the Fed is the "comprehensiveness of our supervisory approach, particularly when compared to alternatives such as Office of Thrift Supervision or [SEC] holding company supervision. Concerns about the [Fed's] supervisory approach relate to both its extent (reach into the broader holding company and unregulated subsidiaries) as well as nature (intrusiveness).' See Federal Reserve System (2008); Financial Crisis Inquiry Commission (2011), pp. 150-155; Labaton (2008).
} 
attract FDIC-insured deposits without becoming subject to supervision by the Fed. ${ }^{35}$ Likewise, in the EU, financial prudential regulation and supervision was focused on banks. ${ }^{36}$ In consequence, regulators failed to identify the build-up of excessive risk in the financial markets and non-bank financial institutions.

\subsection{The Rise of Shadow Banking}

The limited perimeter of prudential regulation, the focus on bank supervision and the lack of prudential regulation in the shadow banking sector were informed by the belief that only the banking sector could pose systemic risk. Infamous bank runs clearly contributed to this belief. As shadow banking institutions do not attract insured deposits '[t]here was little concern of a bank run' regarding such institutions. $^{37}$ The reasoning was that such an institution could be left to fail. Furthermore, in a worst-case scenario the government was not liable to refund the insured deposits. Investors who contracted with these firms were supposedly aware of the risks. Indeed, it was thought that an increase in market-based credit intermediation, supplementing the credit provision by banks, would diminish systemic risk. ${ }^{38}$ This proved incorrect.

Financial institutions, eager to take advantage of regulatory gaps, increasingly moved financial intermediation outside the regulatory perimeter of the traditional banking sector. ${ }^{39}$ There they could perform bank-like maturity and liquidity transformation combined with highly leveraged funding structures, while largely unchecked by prudential regulation and oversight. In so far as regulation was present-mostly through securities and insurance regulation-it predominantly focused on market efficiency, transparency, integrity, and consumer and investor protection. ${ }^{40}$ Moreover, as these activities fell outside the regulatory perimeter of banks, regulators were poorly equipped to spot the systemic risks they presented. $^{41}$ The premise that systemic risk was limited to the banking sector led to gaps in

\footnotetext{
35 In order to win the securities industry's support for the repeal of the Glass-Steagall Act, they were allowed to own thrifts and industrial loan companies. Through these entities, deposits could be attracted without supervision by the Fed. Merrill Lynch and Lehman used such subsidiaries to finance their mortgage origination activities. See Financial Crisis Inquiry Commission (2011), p. 151.

36 The geographical fragmentation of supervision between Member States proved inadequate to safeguard financial stability in regard to international operating banks. This is illustrated by Schoenmaker's financial trilemma. See Schoenmaker (2013).

37 Financial Crisis Inquiry Commission (2011), p. 33. See also the report of the de Larosière Group on the future of European financial regulation and supervision (de Larosière Report), which finds that: 'The conventional wisdom has been that light regulatory principles could apply to [institutions which engage in proprietary trading] because they were trading "at their own risk". Evidence has shown that the investment banks were subject to very thin capital requirements, became highly leveraged and then created severe systemic problems.' See de Larosière et al. (2009), p. 24.

38 Armour et al. (2016), p. 434.

39 Acharya et al. report that regulatory arbitrage motivated banks to set up conduits to securitise assets and provide explicit guarantees for those assets. However, risks did not, in effect, really shift from the banks, although this did reduce their regulatory capital requirements. See Acharya et al. (2013).

40 Moloney (2014a), p. 2.

41 Armour et al. (2016), p. 434.
} 
regulation and supervision in the financial sector. ${ }^{42}$ Indeed, banking regulation, such as the Basel capital frameworks, did not account for, and thus encouraged, the shifting of risks off the balance sheet. ${ }^{43}$

While precise definitions of 'shadow banking' vary, we will adopt the Financial Stability Board's definition, namely 'the system of credit intermediation that involves entities and activities outside the regular banking system'. ${ }^{44}$ The FSB propagates a 'wide net' approach to defining the shadow bank sector, focusing on 'credit intermediation that takes place in an environment where prudential regulatory standards and supervisory oversight are either not applied or are applied to a materially lesser or different degree than is the case for regular banks engaged in similar activities'. ${ }^{5}$ This includes inter alia money market funds, hedge funds, insurance companies, mutual funds, structured investment vehicles and pension funds.

The shadow banking sector expanded rapidly in the years leading up to the crisis. Using a broad definition of non-bank credit intermediaries, the FSB gauged that the total assets in the global shadow banking sector had increased from \$26 trillion in 2002 to $\$ 62$ trillion in $2007 .{ }^{46}$ More recently, the FSB assessed the total assets of non-bank financial intermediation of 20 jurisdictions and the euro area at \$137 trillion, representing about $40 \%$ of total financial system assets. ${ }^{47}$ In addition to its wide net approach, the FSB developed a narrow measurement methodology to narrow down shadow bank monitoring to those elements of non-bank credit intermediation where important risks may exist or are most likely to emerge. According to this measure, shadow banking amounted to $\$ 34$ trillion at the end of 2015 for 26 jurisdictions. ${ }^{48}$ This is $3.2 \%$ more than in the previous year. In the EU, the size of the broadly defined shadow banking sector amounted to $€ 37$ trillion in

\footnotetext{
42 In this regard the de Larosière report found that: 'There was little knowledge of either the size or location of credit risks. While securitised instruments were meant to spread risks more evenly across the financial system, the nature of the system made it impossible to verify whether risk had actually been spread or simply re-concentrated in less visible parts of the system. This contributed to uncertainty on the credit quality of counterparties, a breakdown in confidence and, in turn, the spreading of tensions to other parts of the financial sector'. De Larosière et al. (2009), p. 8.

43 De Larosière et al. (2009), p. 9. American Insurance Group, for example, helped European banks to evade regulatory requirements. It did so by providing $\$ 300$ billion of credit insurance for European banks. According to AIG, this was for the purpose 'of providing them with regulatory capital relief rather than risk mitigation in exchange for a minimum guaranteed fee'. See Gros and Micossi (2008).

44 Financial Stability Board (2011c), p. 3. For an extensive overview of the different definitions on shadow banking, see Pacces and Nabilou (2017).

45 Financial Stability Board (2011c), p. 3.

46 This is based on the Aggregating Flow of Funds data from six jurisdictions (Australia, Canada, Japan, Korea, UK and US) and the publicly-available euro area data from the European Central Bank (ECB). See Financial Stability Board (2011c).

47 This includes 'Other Financial Institutions', pension funds and insurance companies. 'Other Financial Institutions' are all financial institutions that are not classified as banks, insurance companies, pension funds, public financial institutions, central banks, or financial auxiliaries. See Financial Stability Board (2015b).

48 Financial Stability Board (2017b), p. 3.
} 
total assets at the end of 2015. This equals $36 \%$ of the total EU financial sector assets and constitutes a growth of $27 \%$ since $2012 .{ }^{49}$

Just as in the traditional banking sector, credit intermediation in the shadow banking sector revolves around the transformation of maturities. ${ }^{50}$ Short-term debt is used to fund securitised assets such as Asset-Backed Securities (ABS). However, a key characteristic of shadow banking is that it does not fund itself with deposits. Instead, funds are attracted through a variety of wholesale short-term borrowing markets. These include commercial paper, asset-backed commercial paper (ABCP), unsecured interbank lending, and secured repo borrowing. ${ }^{51}$

\subsection{The Risks of Shadow Banking}

Credit intermediation which is performed through the shadow banking sector and is not driven by regulatory arbitrage can generate economic value ${ }^{52}$ and render the financial system more resilient by providing an alternative to bank funding. ${ }^{53}$ However, when non-bank institutions perform bank-like activities-i.e. engage in maturity and liquidity transformation and employ leverage-without being subject to prudential regulation and supervision, financial stability may be jeopardised. ${ }^{54}$ Shadow banking activities that derive their value (exclusively) from avoiding costly regulation thus proved to be a central weakness of the financial system. ${ }^{55}$ It follows that the less stringent-or even lack of - regulation and supervision of the shadow banking sector was not in accordance with the systemic risks posed by it. ${ }^{56}$ These risks manifested themselves in 2008 when the lack of proper oversight, regulation and a fiscal backstop, in combination with high leverage and maturity mismatches,

\footnotetext{
49 European Systemic Risk Board (2016a).

50 Hal S. Scott notes that '[a]lthough the actual steps in the intermediation of financial assets varies, the economic outcome of the process is virtually identical to the depository banking intermediation process: long-term assets are converted to short-term debt instruments, often with exceptionally short maturities. In 2008, for example, $69 \%$ of total outstanding commercial paper had maturities of 1-4 days and $75 \%$ of 9 days or less'. See Scott (2016), p. 69.

51 Scott (2016), p. 68.

52 Value can be derived through specialisation and, related, efficiency gains. See Pozsar et al. (2010), pp. 45-46; Schwarcz (2011), p. 624.

53 The Commission's Action Plan on Building a Capital Markets Union is, in part, based on the premise that 'integrated financial and capital markets can help Member States, especially those inside the euro area, share the impact of shocks. By opening up a wider range of funding sources, it will help to share financial risks and mean that EU citizens and companies are less vulnerable to banking contractions.' See European Commission (2015a).

54 Lax oversight on the shadow banking sector, was for example apparent in the US, where the US Securities and Exchange Commission (SEC) was charged with regulating money market funds and securities firms. As its mandate was limited to the protection of investors it did not, besides imposing capital requirements on broker dealers, focus on the safety and soundness of the firms. As a consequence, they could hold an unchecked amount of leverage. As Paul Volcker put it 'there was no regulation'. See Financial Crisis Inquiry Commission (2011), p. 33.

55 As Adrian et al. found 'it was only a matter of time before intermediation designed to evade public oversight would end badly, as occurred during the post-2007-08 credit cycle'. See Adrian et al. (2015), p. 379.

56 See, for instance: Bernanke (2012), p. 8.
} 
created such vulnerabilities that a relatively small shock could trigger widespread panic in the financial markets.

Such a shock occurred in 2007-2008 when a downturn in the US housing and mortgage market, provoked by excessive credit provision, led to losses on subprime mortgages and associated financial products. ${ }^{57}$ Although the losses on subprime mortgages were substantial, running into the hundreds of billions of dollars, they were relatively small in the context of the total financial system. For example, the losses from subprime mortgages were no larger than those suffered when the Dotcom Bubble burst. ${ }^{58}$ However, the consequences were substantially worse. This was because the subprime mortgage crisis interacted with and exposed deeper systemic vulnerabilities in the financial system ${ }^{59}$ in ways which did not occur in the case of the Dotcom Bubble. ${ }^{60}$

Financial institutions had, through innovative financial engineering, created highly complex financial products. As the market shifted from an originate-to-hold to an originate-to-distribute model, loans were packaged as securities and sold to other financial institutions. Although such products can be used to allocate resources to where they are of most value, it can also reduce the stability of the financial system. ${ }^{61}$ Their complexity makes it hard to assess the risks involved, leading to investment in financial products which, in hindsight, were highly toxic. ${ }^{62}$ Additionally, and crucially, many risky financial instruments were held on the

\footnotetext{
57 Pozsar et al. point out that the shadow banking sector 'contributed significantly to asset bubbles in residential and commercial real estate markets prior to the financial crisis'. See Pozsar et al. (2010), abstract.

58 Hellwig and Admati note that the $\$ 500$ billion loss from subprime-mortgage-related securities is dwarfed by the more than $\$ 5$ trillion of losses in the value of shares on US stock markets in the early 2000s, when the so-called technology bubble of the late 1990s burst'. See Admati and Hellwig (2014), p. 60 .

59 Ben Bernanke has identified the following underlying systemic vulnerabilities: 'In the private sector, some key vulnerabilities included high levels of leverage; excessive dependence on unstable short-term funding; deficiencies in risk management in major financial firms; and the use of exotic and nontransparent financial instruments that obscured concentrations of risk. In the public sector, my list of vulnerabilities would include gaps in the regulatory structure that allowed systemically important firms and markets to escape comprehensive supervision; failures of supervisors to effectively apply some existing authorities; and insufficient attention to threats to the stability of the system as a whole (that is, the lack of a macroprudential focus in regulation and supervision)'. See Bernanke (2012).

60 When the Dotcom Bubble burst, shareholders suffered losses on dramatically overpriced tech companies. These shareholders were mostly final investors, as financial institutions held a relatively small amount of these shares. While these shareholders ended up with substantial losses on their equity holdings, they were not transmitted to other institutions and did not cause widespread financial instability. Hellwig and Admati point out that had banks owned $10 \%$ of the shares of listed companies, their losses would have been greater than the subprime losses. See Admati and Hellwig (2014), p. 256.

61 Kenneth R. French et al. find that there is 'a trade-off between financial innovation and stability'. See French et al. (2010), p. 25.

62 Martin Wolf notes that 'risk had been distributed not to those best able to bear it, but to those least able to understand it'. See Wolf (2014), p. 19.
} 
balance sheets of financial institutions. ${ }^{63}$ Subsequent losses on subprime-related financial products proved devastating for the highly leveraged financial firms which held them on their balance sheets. Those losses extended well beyond the banking sector. Shadow bank entities such as investment funds, insurance companies (including monoline insurers which guaranteed mortgage securities) and other institutional investors all experienced massive losses related to the subprime mortgage market. It should be recalled that banks and shadow banking entities are highly interconnected as many different financial institutions are involved at various stages of the credit intermediation process. ${ }^{64}$ Banks shifted risks off their balance sheets and into shadow bank entities in order to take advantage of regulatory arbitrage. However, when these entities failed, banks sometimes preferred to support them beyond their contractual obligation or equity ties, mainly to avoid reputational risks. ${ }^{65}$ This is referred to as 'step-in' risk, as it provides an additional channel of contagion between the banking and the shadow banking system. ${ }^{66}$ As a consequence, the systemic relevance of shadow bank entities stems for a large part from their connectedness with the rest of the financial system. ${ }^{67}$

During the Global Financial Crisis, authorities were forced to take a range of unconventional measures to provide liquidity and stability to the financial markets, starting with their traditional function of lender of last resort. In the US the Fed provided a discount window to eligible commercial banks. This proved ineffective as concerns of being stigmatised made banks hesitant to use it. ${ }^{68}$ Furthermore, for

\footnotetext{
63 Indeed, Raghuram G. Rajan finds that 'the central cause for the financial panic was not so much that the banks packaged and distributed low-quality subprime mortgage-backed securities but that they held on to substantial quantities themselves, either on or off their balance sheets, financing these holdings with short-term debt'. See Rajan (2011), p. 17.

${ }^{64}$ Cetorelli points out that at least part of such a 'credit intermediation chain' operates 'outside the purview of the prudential regulator and without explicit access to government backstops traditionally available to prudentially regulated intermediaries'. She also observes an ongoing trend of commercial banks evolving into 'increasingly complex financial conglomerates, integrating under common ownership and control the non-bank entities operating along the modern credit intermediation chains'. Cetorelli (2014), pp. 5-6. For a first study on the exposures of EU banks to shadow banking entities within the global financial system, see Abad et al. (2017).

65 Basel Committee on Banking Supervision (2017), p. 1.

66 A staff report from the Federal Reserve Bank of New York found that in the month following Lehman's failure 29 Money Market Funds (MMFs) would have 'broken the buck' without guarantees from their sponsors. See McCabe et al. (2012), p. 30. The systemic risk posed by MMFs in the EU has been recognised by the Commission, which found that '[d]uring periods of high market turbulence, it is difficult for these funds to maintain liquidity and stability, particularly in the face of investor runs. Consequently, they could pose a serious risk of contagion'. See European Commission (2013).

67 Due to the inter-institutional connectedness of financial institutions local shocks, amplified further by contagion effects, may turn into a broader systemic crisis. For instance, the primary counterparties of investment banks were many of the largest commercial banks. The ESRB has also recognised that banks are highly interconnected with shadow banking entities. It found that over $8 \%$ of euro area banks assets are linked to euro area investment funds and other financial institutions through loans, debt securities and equity or investment fund shares. See European Systemic Risk Board (2017), p. 3. See also: Schwarcz and Zaring (2016), p. 12; Anabtawi and Schwarcz (2011), pp. 1352-1355; For an analysis of the role of connectedness, correlation and contagion, see Scott (2016).

68 'The problem with the discount window is that people don't like to use it because they view it as a risk that they will be viewed as weak', according to William Dudley, then head of the capital markets group at the New York Fed. See Financial Crisis Inquiry Commission (2011), p. 274.
} 
the purposes of the broader financial system, the Fed normally relied on the banks to lend part of the received liquidity to solvent non-bank institutions. But this did not happen to the extent that it had in the past. ${ }^{69}$ This led to a number of programmes for the provision of liquidity to primary dealers. ${ }^{70}$ Despite these efforts, Lehman Brothers-a shadow bank-filed for bankruptcy on 15 September $2008 .^{71}$

After Lehman Brother's bankruptcy the markets for the rollover of short-term debt, through interbank lending, repo and $\mathrm{ABCP}$, froze. ${ }^{72}$ Uncertainty about the institutions' health and about the prices of posted collateral caused lenders to stop extending credit. $^{73}$ Reserve Primary Fund, a money market fund (MMF), had heavily invested in commercial paper issued by Lehman Brothers. During the days following Lehman's bankruptcy, redemption requests to Reserve Primary constituted about half of the fund's liabilities. This caused Reserve Primary to 'break the buck' on 16 September 2008 when shares were redeemed below their $1 \$$ face value. This caused money market funds to experience run-like behaviour. ${ }^{74}$ This in turn left the US Department of Treasury no other option than to guarantee a net asset value of $\$ 1$ on the shares of all MMFs in order to relieve panic in the financial markets.

Another notorious example of underperforming supervision, and the systemic risks posed by a shadow bank entity, was apparent in the case of American International Group (AIG). AIG's Financial Products subsidiary sold enormous amounts of credit default swaps. Being adept at regulatory arbitrage, it managed to select the regulator least likely to restrict its practices: the Office of Thrift Supervision. $^{75}$

\footnotetext{
${ }^{69}$ William Dudley stated in an interview for the FCIC: 'I don't think people going in really had a full understanding of the complexity of the shadow banking system, the role of [structured investment vehicles] and conduits, the backstops that banks were providing SIV conduits either explicitly or implicitly'. See Financial Crisis Inquiry Commission (2011), p. 275.

${ }^{70}$ On 11 March 2008, the Fed launched the Term Securities Lending Facility which allowed primary dealers to temporarily exchange eligible collateral for Treasury securities. On 16 March 2008, the Fed enlarged the scope of the discount window to primary dealers, including investment banks.

71 The decision not to bailout Lehman Brothers was in part motivated by the wish not to aggravate the moral hazard problem, partially because markets were thought to have had sufficient time to prepare for Lehman's demise. Additionally, the Treasury and Fed adopted the position that they lacked the legal authority to save Lehman. This argument revolved around the assessment that Lehman was not only illiquid but also insolvent, which rendered it ineligible for a loan under section 13(3) of the Federal Reserve Act. See Blinder (2013), pp. 126-127.

72 Brunnermeier (2009); Acharya et al. (2011); Financial Crisis Inquiry Commission (2011), chapters 13 and 14; Deyoung (2015), p. 842.

${ }^{73}$ See Gorton and Metrick (2012); French et al. (2010), p. 24.

${ }^{74}$ This problem was not confined to US money market funds but also extended to Europe. See Bengtsson (2013).

75 To select the Office of Thrift Supervision as regulator, companies needed a thrift subsidiary. AIG subsequently acquired a few small savings banks. This caused Ben Bernanke to exclaim that: 'If there's a single episode in this entire 18 months [of the financial crisis] that has made me more angry, I can't think of one than AIG'. He went on to say, 'I think AIG exploited a huge gap in the regulatory system, there was no oversight of the financial products division. This was a hedge fund basically that was attached to a large and stable insurance company, made huge numbers of irresponsible bets, took huge losses'. Sender (2009).
} 
As has been extensively noted, the consequences of Lehman's bankruptcy were more severe than imagined. ${ }^{76}$ After Lehman, the scale and number of government programmes rapidly increased.

Most significantly, US Congress appropriated $\$ 700$ billion for the Troubled Asset Relief Program (TARP) on 3 October 2008, which allowed the Treasury to inject equity into failing financial institutions. ${ }^{77}$ Consequently-between the liquidity facility, lending programs and asset purchasing programs by the Fed and the guarantees provided by the FDIC and the US Treasury-a near complete backstop was created during the crisis for the shadow banking sector. ${ }^{78}$ In this regard Barry Eichengreen noted that 'the failure to endow the Treasury and the Fed with the authority to deal with the insolvency of non-bank financial institutions was the single most important policy failure of the crisis'. ${ }^{79}$

Meanwhile, Europe lacked a robust pan-European approach to failing financial institutions. National governments were left to their own devices. However, this fragmentation along national borders was not reflected by financial institutions. Benefiting from the unification of the European markets, they had stretched their operations over many countries. In 2008, panic on the financial markets culminated in a joint commitment by the EU leaders to support the major financial institutions and avoid their bankruptcy by providing sufficient liquidity, funding and capital resources. ${ }^{80}$ As a consequence, between 2008 and 2012 national authorities spent a total of $€ 1.5$ trillion on state aid in support of the financial system. ${ }^{81}$

Many of the financial institutions which had to be bailed out because of the systemic risk consequences-commonly referred to as Too-Big-To-Fail-were in fact non-bank financial institutions. They ranged, inter alia, from investment banks (e.g. Bear Stearns and Merrill Lynch) and insurance companies (AIG) ${ }^{82}$ to asset managers (Reserve Primary Fund).

In conclusion, the belief that shadow banking activities did not pose systemic risks proved to be false. One of the important lessons from the Global Financial Crisis was that the failure of non-bank financial institutions can-and has-created systemic risk, especially through their interconnectedness with and contagion of the wider financial system. ${ }^{83}$ Financial institutions which deal in bank-like risks by providing maturity and/or liquidity transformation, and high leverage are particularly susceptible to shocks. Shadow banks relied heavily (although not exclusively)

\footnotetext{
76 See, for instance, Blinder (2013), p. 127.

77 TARP was enacted through the Emergency Economic Stabilization Act.

78 Pozsar et al. (2010), p. 71.

79 Eichengreen (2015), p. 5.

${ }^{80}$ Council of the European Union (2008).

81 European Commission (2014), p. 3.

82 For an elaborate exposition on systemic risks in the insurance industry, see Schwarcz and Schwarcz (2014). They argue not only that individual insurance-focused, non-bank financial institutions can become systemically relevant but also that the correlation among individual insurance companies could contribute to or cause financial instability.

83 Such interconnectedness is, for example, apparent from the fact that banks obtain a substantial part of their funding from money market funds and rely on them to roll over short-term debt. See Bengtsson (2013), p. 582. See also: Financial Stability Board (2011c); Pozsar et al. (2010).
} 
on short-term liabilities for funding. ${ }^{84}$ Short-term funding, typically through (overnight) asset-backed commercial paper and repos, requires the institution to roll over its debt when it matures. This rendered shadow banking entities vulnerable to runs on their short-term funding, equivalent to bank runs. ${ }^{85}$ Indeed, lacking funding through insured deposits they were even more vulnerable to runs, whereby panic could easily lead to contagion. ${ }^{86}$ Risks posed by shadow bank entities were aggravated by the fact that such institutions were only subjected to light regulation and supervision. In consequence, the belief that no fiscal backstop to the shadow banking sector was necessary proved equally false: during the crisis large publicly funded bailouts proved necessary.

While the foregoing illustrates the enormous threat posed by the shadow banking sector as exemplified during the Global Financial Crisis, it must be stressed that the financial sector is constantly changing and evolving. Specific risks which manifested themselves in the past may diminish, while other, new, risks materialise. ${ }^{87}$ Future financial crises will probably not mirror previous crises and have different roots. It is therefore crucial to have a forward-looking system in place for identifying potential systemic risks in the financial sector. And once such risks have been identified, they must be brought within a commensurate regulatory perimeter. $^{88}$

\footnotetext{
${ }^{84}$ Bear Stearns was borrowing over $\$ 100$ billion in the repo market by the end of 2007. At the end of the first quarter of 2008 Lehman Brothers was borrowing nearly $\$ 200$ billion through repos. Both investment banks were supervised by the SEC. See Blinder (2013), chapter 5.

${ }^{85}$ Gorton and Metrick find that 'The 2007-2008 financial crisis was a system wide bank run. What makes this bank run special is that it did not occur in the traditional-banking system, but instead took place in the "securitized-banking" system. A traditional-banking run is driven by the withdrawal of deposits, a securitized-banking run is driven by the withdrawal of repurchase (repo) agreements.' See
} Gorton and Metrick (2012), p. 425.

${ }^{86} \mathrm{Hal} \mathrm{S}$. Scott notes that 'short-term financing sources are subject to the same collective action problems and run risks that have historically plagued uninsured bank deposits'. See Scott (2016), p. 69. Hal S. Scott argues that contagion was the most destructive feature during the Global Financial Crisis. While connectedness indicates overexposure of financial institutions to one another-where failure of the one brings about the failure of the other-contagion denotes an indiscriminate run by short-term creditors of financial institutions. It can, consequently, render otherwise solvent institutions insolvent. Scott indicates that given the existence of $\$ 7.4$ to $\$ 8.2$ trillion of runnable and uninsured short-term liabilities, contagion remains the most important part of systemic risk facing the financial system. The fact that about $60 \%$ of these runnable liabilities are held by non-bank financial entities underlines the importance of properly regulating non-bank financial institutions as well. See Scott (2016), p. xvi.

${ }^{87}$ As noted by the FSB, aspects of shadow banking which contributed to the financial crisis have declined significantly (e.g. the use of subprime residential mortgage-backed securities and collateralised debt obligations has diminished) and generally no longer pose financial stability risks. However, the volume of asset management activities, which entail their own specific risks, has risen sharply. The FSB also notes that new forms of shadow banking are likely to develop in the future. See Financial Stability Board (2017a).

${ }^{88}$ This is in line with the de Larosière report which recommends that regulation must extend, in a proportionate manner, to all firms or entities conducting financial activities which may have a systemic impact. De Larosière et al. (2009), p. 23. 


\section{International Initiatives to Address Systemic Risk Posed by Non-Bank Financial Institutions}

As seen above, systemic risk is not confined to the banking system. This calls into question the notion that systemic risk can be controlled by focusing chiefly on bank regulation and supervision. Shadow banks operating outside the regulatory perimeter for banks were able to accumulate systemic risks virtually unchecked. Unlike the jurisdiction of financial supervisors, the build-up of systemic risk was not confined to particular countries or sectors. Furthermore, by focusing on the microprudential health, the authorities overlooked and neglected supervision of the safety of the financial system as a whole. This is not to say that the regulation and supervision of banks did not need improving, as it clearly did, but a one-sided focus on bank regulation failed to take account of the risks and consigned them to the shadow sector.

A range of international initiatives designed to increase financial stability were undertaken in response. During the G20 London summit in 2009 it was agreed, among other things, that regulators and supervisors must reduce the scope for regulatory arbitrage. To this end, regulation and oversight should extend to 'all systemically important financial institutions, instruments and markets' ${ }^{89}$ A few months later, at the G20 Pittsburgh summit, the world leaders reiterated that 'all firms whose failure could pose a risk to financial stability must be subject to consistent, consolidated supervision and regulation with high standards' ${ }^{90}$ It is, therefore, important to have an adequate regulatory perimeter which ensures that all financial activities and institutions that may pose systemic risk are appropriately regulated. ${ }^{91}$ The supervision of individual financial institutions has to take into account-and be complemented by-supervision of the robustness of the financial system as a whole. This is referred to as macroprudential supervision. ${ }^{92}$

The G20 tasked a new organ, the Financial Stability Board (FSB), with the development and coordination of a comprehensive framework for global regulation and oversight of the global financial system. ${ }^{93}$ As part of this task, the FSB has been designing policy recommendations addressing the Too-Big-To-Fail problem of SIFIs, while at the same time preventing regulatory arbitrage as stricter regulation in one sector might lead to migration of risky activities elsewhere. ${ }^{94}$

In order to alleviate Too-Big-To-Fail, the FSB requires a number of integrated policies comprising:

- Resolution instruments which enable authorities to resolve financial institutions in an orderly manner.

\footnotetext{
${ }^{89}$ G20 (2009a).

90 G20 (2009b).

91 Carvajal et al. (2009).

92 Lastra (2015), p. 315.

93 The Financial Stability Board was established at the G20 2009 London summit as a successor to the Financial Stability Forum.

94 Financial Stability Board (2013a).
} 
- Resolvability assessments and recovery and resolution planning for global systemically important financial institutions, and for the development of institution-specific cross-border cooperation agreements.

- Requirements for financial institutions determined to be globally systemically important to have additional loss absorption capacity tailored to the impact of their default.

- More intensive and effective supervision of all SIFIs. ${ }^{95}$

According to the FSB, the crisis revealed that some supervisors failed to make appropriate risk assessments leading to an unwarranted assertion that institutions were highly capitalised and liquid, even as some later failed. In consequence, the FSB assessed that the supervision of SIFIs 'must clearly be more intense, more effective, and more reliable'. 96

This resulted in a number of recommendations in regard to supervision of SIFIs, including the following:

- National supervisory authorities should have the powers to apply differentiated supervisory requirements and intensity of supervision of SIFIs based on the risk they pose to the financial system.

- All national supervisory authorities should have appropriate mandates, independence and resources to identify risks early and intervene to require changes within an institution, as needed, to prevent unsound practices and take appropriate counter-measures to safeguard against the additional systemic risks.

- Jurisdictions should provide for a national supervisory framework that enables effective consolidated supervision by addressing ambiguities of responsibilities, impairments related to information gathering and assessment when multiple supervisors are overseeing the institution and its affiliates. ${ }^{97}$

\subsection{Determining Systemic Risk}

Reducing the systemic and moral hazard risks posed by SIFIs starts with the identification of such institutions. For this purpose international methodologies have been created for identifying global systemically important banks (G-SIBs) and insurers (G-SIIs). Furthermore, in March 2015 the FSB and the International Organization of Securities Commissions (IOSCO) released a second consultative document regarding the assessment methodologies for identifying Non-Bank NonInsurer Global Systemically Important Financial Institutions. ${ }^{98}$

The latter aims to provide a framework for determining whether a non-bank noninsurer financial entity is globally systemically relevant (NBNI G-SIFI). The proposed methodologies are designed to identify NBNI financial institutions whose

\footnotetext{
95 Financial Stability Board (2010b); Financial Stability Board (2011b).

96 Financial Stability Board (2010a).

97 Financial Stability Board (2010b).

98 Financial Stability Board (2015a), p. 8.
} 
distress or disorderly failure, because of their size, complexity and systemic interconnectedness, would cause significant disruption to the wider financial system and economic activity at the global level. ${ }^{99}$ Besides giving sector specific indicators, it provides basic impact factors that should be taken into account. These are a financial institution's size, interconnectedness, substitutability, complexity and global, cross-jurisdictional, activities.

In regard to asset management activities, the FSB recently presented policy recommendations to address structural vulnerabilities from asset management activities. ${ }^{100}$ As illustrated by the demise of Long Term Capital Management (LTCM), a leveraged hedge fund, and the run on MMFs during the 2008 crisis, asset management structures can pose systemic risk. ${ }^{101}$ The FSB identified four important structural vulnerabilities: (i) liquidity mismatch between fund investments and redemption terms and conditions for open-ended funds; ${ }^{102}$ (ii) leverage; (iii) operational risk and challenges in transferring investment mandates in stressed conditions; (iv) securities lending activities of asset managers and funds.

Besides developing NBNI G-SIFI methodology and making sector-specific recommendations, the FSB has provided a framework for the detection of elevated systemic risk posed by non-bank entities. To this end, it proposes a two-pronged strategy, entailing (1) enhanced monitoring and (2) strengthening of oversight and regulation. ${ }^{103}$ The FSB finds that, when necessary to ensure financial stability, relevant authorities should have the power to bring non-bank financial entities into regulatory and supervisory oversight. Therefore authorities should, as a key prerequisite, have a regime to define, expand, and keep up to date the regulatory perimeter necessary to ensure financial stability. ${ }^{104}$

\subsubsection{Monitoring Non-Bank Financial Entities That Could Pose Financial Stability Risks}

The FSB has adopted a monitoring framework designed to identify the build-up of systemic risks in the shadow banking system. It provides both for a wide-net approach, which captures all non-bank credit intermediation, and a narrow approach. The latter allows authorities to focus on the subset of non-bank credit intermediation where there are (i) developments that increase systemic risk (in particular maturity/liquidity transformation, imperfect credit risk transfer and/or

\footnotetext{
99 Financial Stability Board (2015a), p. 8.

100 Financial Stability Board (2017c).

101 For a detailed history on the demise of LTCM, see Lowenstein (2000). For a detailed account on the run on MMFs see Bengtsson (2013); Kacperczyk and Schnabl (2013); Chernenko and Sunderam (2014).

102 Recently this risk was illustrated by a run on numerous illiquid UK property funds following the Brexit vote. See Goodley and Treanor (2016).

103 See Financial Stability Board (2011c); Financial Stability Board (2013b); Financial Stability Board (2015c).

104 Financial Stability Board (2013b).
} 
leverage), and/or (ii) indications of regulatory arbitrage that is undermining the benefits of financial regulation. ${ }^{105}$

The monitoring of systemic risk must take an risk-based approach in which the extent of a firm's involvement in shadow banking has to be judged by its underlying economic activities, rather than legal names or forms. ${ }^{106}$ This is especially relevant as any non-bank financial institution could perform shadow banking activities. ${ }^{107}$ Such a functional approach allows for a consistent assessment of shadow banking activities and the risk they pose to financial stability. It allows new structures and innovations to fall within the monitoring scope. A comparable approach is present in the FSB's classification of non-bank financial entities into five different economic functions (see Table 1).

The FSB finds that jurisdictions should establish a systematic process involving all relevant domestic authorities in order to review shadow banking risks posed by non-bank financial entities or activities, and ensure that any entities or activities that could pose material risks to financial stability are brought within the regulatory perimeter. ${ }^{108}$ However, in its 2016 thematic review the FSB finds that few jurisdictions have such a systemic process in place. It recommends that, where such a process does not exist, there "may be merit for jurisdictions to establish a systematic process to ensure that non-bank financial entities that could pose financial stability risks are brought within the regulatory perimeter in a timely and proactive manner'. ${ }^{109}$

The US is an example of a jurisdiction which does have in place a systematic process for reviewing the regulatory perimeter and bringing non-bank financial companies within (additional) regulatory and supervisory oversight. The US system will be discussed in more detail in Sect. 4 below.

\subsection{Regulating Non-Bank Systemically Important Financial Institutions}

As stated previously, while shadow bank entities might create systemic risk on their own, risks may also emerge indirectly through the interconnectedness of the shadow and regular banking sectors. Indeed, shadow banks tend to be closely connected with the regulated banking sector due to ownership linkages and explicit and implicit guarantees and as direct counterparties. ${ }^{110}$ For example, the European Systemic Risk Board (ESRB) assesses that approximately $9 \%$ of the euro area credit institutions' assets are loans to the euro area investment funds and Other Financial Institutions (OFI), or debt securities, equity and investment fund shares issued by

\footnotetext{
105 Financial Stability Board (2011c).

106 Financial Stability Board (2013b).

107 Pacces and Nabilou (2017), p. 8.

108 FSB recommendation 1A of the thematic review. See Financial Stability Board (2016).

109 Financial Stability Board (2016), pp. 15-16.

110 European Banking Authority (2015).
} 
Table 1 Classification by economic functions. Source: Financial Stability Board (2017b)

\begin{tabular}{|c|c|c|}
\hline $\begin{array}{l}\text { Economic } \\
\text { Function }\end{array}$ & Definition & Typical entity types \\
\hline EF1 & $\begin{array}{l}\text { Management of collective investment vehicles } \\
\text { with features that make them susceptible to } \\
\text { runs }\end{array}$ & $\begin{array}{l}\text { MMFs, fixed income funds, mixed funds, } \\
\text { credit hedge funds, real estate funds }\end{array}$ \\
\hline $\mathrm{EF} 2$ & $\begin{array}{l}\text { Loan provision that is dependent on short-term } \\
\text { funding }\end{array}$ & $\begin{array}{l}\text { Finance companies, leasing companies, } \\
\text { factoring companies, consumer credit } \\
\text { companies }\end{array}$ \\
\hline EF3 & $\begin{array}{l}\text { Intermediation of market activities that is } \\
\text { dependent on short-term funding or on } \\
\text { secured funding of client assets }\end{array}$ & $\begin{array}{l}\text { Broker-dealers, securities finance } \\
\text { companies }\end{array}$ \\
\hline EF4 & Facilitation of credit creation & $\begin{array}{l}\text { Credit insurance companies, financial } \\
\text { guarantors, monolines }\end{array}$ \\
\hline EF5 & $\begin{array}{l}\text { Securitisation-based credit intermediation and } \\
\text { funding of financial entities }\end{array}$ & $\begin{array}{l}\text { Securitisation vehicles, structured } \\
\text { finance vehicles, asset-backed } \\
\text { securities }\end{array}$ \\
\hline
\end{tabular}

those entities. Conversely, deposits from euro area investment funds and OFI constitute $7 \%$ of credit institution' liabilities. ${ }^{111}$

Regulatory response has thus developed broadly along two, not mutually exclusive, lines. First, efforts have been made to impose regulatory limits on the exposure of the traditional banking sector to the shadow banking sector. And, second, efforts are made to expand the regulatory perimeter to capture non-bank financial institutions.

In regard to the former, the Basel Committee for Banking Supervision has issued a final standard which sets out a supervisory framework for measuring and controlling large exposures. ${ }^{112}$ The Basel exposure framework aims to serve as a backstop to riskbased capital requirements, as it should ensure that the maximum possible loss a bank could incur if a single counterparty or group of connected counterparties were to suddenly fail would not endanger the bank's survival. In effect, this means that the total exposure of a bank to a single counterparty or to a group of connected counterparties must not exceed $25 \%$ of the bank's total amount of Tier 1 capital. ${ }^{113}$ Jurisdictions must implement the large exposure framework in full by 1 January 2019.

In the EU, limits to large exposures are specified in the Capital Requirements Regulation (CRR), which by and large matches the Basel exposure framework. ${ }^{114}$

\footnotetext{
111 European Systemic Risk Board (2016a), p. 6.

112 Basel Committee on Banking Supervision (2014).

113 Basel Committee on Banking Supervision (2014), § 16.

114 Exposures may not exceed $25 \%$ of the institution's eligible capital where the client is a credit institution or an investment firm the exposure may not be higher than $25 \%$ or EUR 150 million. See Regulation (EU) No. 575/2013 of the European Parliament and of the Council of 26 June 2013 on prudential requirements for credit institutions and investment firms and amending Regulation (EU) No. 648/2012 [2013] OJ L176 (CRR), Art. 395.
} 
Additionally, the CCR mandates the European Banking Authority (EBA) to provide guidelines for setting appropriate aggregate limits on shadow banking exposures or tighter individual limits on exposures to shadow banking entities which carry out banking activities outside a regulated framework. In its consultation paper on its draft guidelines, the EBA recognised that the Global Financial Crisis 'has revealed previously unrecognised fault lines which can transmit risk from the shadow banking system to the regulated banking system, putting the stability of the entire financial system at risk'. ${ }^{115}$ In its final guidelines, which came into effect on 1 January 2017, the EBA requires banks and investment firms to identify their individual exposures to shadow banking entities and the potential risks and the impact of those risks arising from these exposures. ${ }^{116}$ These risks must, subsequently, be taken into account within the institution's Internal Capital Adequacy Assessment Process (ICAAP) and capital planning.

In regard to step-in risks-i.e. financial support granted by a bank to a troubled non-bank financial entity, beyond any contractual obligations-the Basel Committee on Banking Supervision has published a consultative document on guidelines for the identification and management of such risks. ${ }^{117}$

\subsubsection{Non-Bank SIFI Regulation}

In regard to the expansion of the regulatory perimeter to ensure that it encompasses non-bank financial institutions and activities that could pose financial stability risks, the FSB has developed policy recommendations for strengthening the oversight and regulation of shadow banking sectors. ${ }^{118}$

The FSB presents a policy framework, consisting of overarching principles that authorities should apply for all economic functions and a specific toolkit for each economic function, in order to mitigate systemic risks posed by a shadow banking entity associated with its specific economic function (see Table 2). ${ }^{119}$

After being tasked by the G20 with addressing Too-Big-To-Fail problems, the FSB also produced a number of policy recommendations designed to reduce the chance of failure of financial institutions and minimise the impact of any such failure. Of primary importance are its Key Attributes of Effective Resolution Regimes for Financial Institutions (KA), which set out the core elements that the FSB considers necessary for an effective resolution regime.

The FSB recommends that any financial institution that could be systemically significant or critical if it fails should be subject to a resolution regime. Resolution should be initiated when a financial institution is no longer viable or likely to be no longer viable, and when it has no reasonable prospect of becoming viable again.

Effective resolution regimes should, according to the FSB:

\footnotetext{
115 European Banking Authority (2015), p. 4.

116 European Banking Authority (2016).

117 Basel Committee on Banking Supervision (2017).

118 Financial Stability Board (2011c).

119 Financial Stability Board (2013b).
} 
Table 2 Most commonly reported policy tools to address shadow banking risks (by EF). Source: Financial Stability Board (2016)

\begin{tabular}{|c|c|c|c|}
\hline $\begin{array}{l}\text { Economic } \\
\text { function }\end{array}$ & Entity type(s) & Most material risk & Policy tools available \\
\hline EF1 & $\begin{array}{l}\text { Open-ended } \\
\text { investment funds }\end{array}$ & $\begin{array}{l}\text { Liquidity } \\
\text { transformation }\end{array}$ & $\begin{array}{l}\text { Redemption gates; suspension of } \\
\text { redemptions; redemption fees or other } \\
\text { redemption restrictions; side pockets; } \\
\text { limits on investments in illiquid assets; } \\
\text { liquidity buffers; limits on asset } \\
\text { concentration; limits on leverage; } \\
\text { restrictions on maturity of portfolio assets }\end{array}$ \\
\hline EF1 & $\begin{array}{l}\text { Alternative } \\
\text { investment funds/ } \\
\text { hedge fluids }\end{array}$ & $\begin{array}{l}\text { Maturity } \\
\text { transformation and } \\
\text { leverage }\end{array}$ & $\begin{array}{l}\text { Redemption gates; suspension of } \\
\text { redemptions; redemption fees or other } \\
\text { redemption restrictions; side pockets; } \\
\text { limits on investments in illiquid assets; } \\
\text { liquidity buffers; limits on asset } \\
\text { concentration; restrictions on maturity of } \\
\text { portfolio assets; lock-up periods }\end{array}$ \\
\hline $\mathrm{EF} 2$ & Finance companies & Leverage & $\begin{array}{l}\text { Bank prudential regulatory regimes; capital } \\
\text { requirements; liquidity buffers; leverage } \\
\text { limits; limits on asset concentration/large } \\
\text { exposures; restrictions on types of } \\
\text { liabilities }\end{array}$ \\
\hline EF3 & Broker-dealers & Leverage & $\begin{array}{l}\text { Prudential regime; capital requirements; } \\
\text { limiting re-hypothecation of client assets }\end{array}$ \\
\hline EF4 & $\begin{array}{l}\text { Insurance/mortgage } \\
\text { guarantee } \\
\text { companies }\end{array}$ & $\begin{array}{l}\text { Imperfect credit risk } \\
\text { transfer }\end{array}$ & $\begin{array}{l}\text { Capital requirements; size/scope of business } \\
\text { restrictions; enhanced risk management, } \\
\text { risk sharing; consolidation rules and risk } \\
\text { retention }\end{array}$ \\
\hline EF5 & $\begin{array}{l}\text { Securitization } \\
\text { entities }\end{array}$ & $\begin{array}{l}\text { Leverage, liquidity } \\
\text { and maturity } \\
\text { transformation }\end{array}$ & $\begin{array}{l}\text { Restrictions on eligible collateral; } \\
\text { restrictions on exposures to/from banks; } \\
\text { restrictions on liquidity and maturity } \\
\text { transformation }\end{array}$ \\
\hline
\end{tabular}

(i) ensure continuity of systemically important financial services, and payment, clearing and settlement functions;

(ii) protect, where applicable and in coordination with the relevant insurance schemes and arrangements, such depositors, insurance policy holders and investors as are covered by such schemes and arrangements, and ensure the rapid return of segregated client assets;

(iii) allocate losses to firm owners (shareholders) and unsecured and uninsured creditors in a manner that respects the hierarchy of claims;

(iv) not rely on public solvency support and not create an expectation that such support will be available;

(v) avoid unnecessary destruction of value, and therefore seek to minimise the overall costs of resolution in home and host jurisdictions and, where consistent with the other objectives, losses for creditors; 
(vi) provide for speed and transparency and as much predictability as possible through legal and procedural clarity and advanced planning for orderly resolution;

(vii) provide a mandate in law for cooperation, information exchange and coordination domestically and with relevant foreign resolution authorities before and during a resolution;

(viii) ensure that non-viable firms can exit the market in an orderly way; and

(ix) be credible, and thereby enhance market discipline and provide incentives for market-based solutions. ${ }^{120}$

\section{Policy Response in the United States-Systemic Risk Regulation}

This section discusses some notable regulatory reforms in the US in relation to the identification and subsequent regulation and supervision of non-bank systemically important financial institutions. The US practice can provide valuable insights for possible European reform along the same or similar lines.

As illustrated in Sect. 2, systemic risk in the US manifested itself not only in the traditional banking sector but also to a significant degree in the shadow banking sector. Activities in the lightly regulated shadow banking sector-e.g. investment banks and money market funds-proved the most damaging. The combination of high leverage and the dependence on short-term (overnight) funding to finance longterm investments rendered non-bank financial institutions susceptible to modern bank runs. The withdrawal of funds, or refusal to roll over existing debt, forced fire sales, which led to a further decline in asset prices. As asset prices deteriorated, the solvency of other financial institutions holding similar assets became uncertain, freezing short-term funding and leading to additional fire sales. ${ }^{121}$

The main regulatory response of the crisis was the Dodd-Frank Act, which was signed into law by President Obama on 21 July 2010. Its chief goal was to address the issues of financial stability and systemic risk and to prevent further bailouts of the financial system at the taxpayers' expense. ${ }^{122}$ The Dodd-Frank Act applies a more risk-based approach to the identification and regulation of non-bank SIFIs in two notable ways. First, by introducing a Financial Stability Oversight Council (FSOC), a new federal regulator, charged with monitoring systemic risk and determining what non-bank financial institutions could pose a threat to the financial stability of the US. Second, it creates a resolution regime for non-bank financial institutions whose failure poses a significant risk to the financial stability of the US. Both reforms are discussed in the following sections.

\footnotetext{
120 Financial Stability Board (2011a).

121 See, for example, Admati and Hellwig (2014), p. 93; Scott (2016), chapter 7.

122 Dodd-Frank Act, Preamble.
} 


\subsection{Designation by the Financial Stability Oversight Council}

In general, the FSOC has two main tasks. First, to identify risks to the financial stability of the US emanating from non-bank financial institutions. Second, to respond to emerging threats to the stability of the United States financial system. ${ }^{123}$

The FSOC is charged with determining whether a non-bank financial company ${ }^{124}$ is systemically important. ${ }^{125}$ The designation may be made by an affirmative vote of at least two-third of the FSOC's voting members, including the Chairperson. In consequence, a designated company is supervised by the Board of Governors of the Federal Reserve System (FRB) and is subject to the prudential standards set in Title I of the Dodd-Frank Act.

More specifically, a designation may be made under either of two determination standards: (i) when material financial distress at the company could pose a threat to the financial stability of the US; or (ii) when the very 'nature, scope, size, scale, concentration, interconnectedness, or mix' of the company's activities could pose the same threat. ${ }^{126}$

Industry practitioners, commenting on the scope of the FSOC's non-bank SIFI determination, found that the particular segment of the financial industry they represented does not pose a threat to US financial stability and should not generally be subject to a determination. ${ }^{127}$ The FSOC, however, contended that it does not intend to provide industry-based exemptions from potential non-bank SIFI determinations. Instead it will apply the statutory standards to determine whether a non-bank financial company qualifies as systemically important. ${ }^{128}$ The Dodd-

${ }^{123} 12$ US Code $\S 5322$. Additionally the FSOC has to promote market discipline by eliminating expectations on the part of shareholders, creditors, and counterparties of systemically important institutions that the government will shield them from losses in the event of failure.

${ }^{124}$ A company is predominantly engaged in financial activities if (i) 'the annual gross revenues derived by the company and all of its subsidiaries from activities that are financial in nature and, if applicable, from the ownership or control of one or more insured depository institutions, represents 85 percent or more of the consolidated annual gross revenues of the company'; or (ii) 'its gross annual revenue or the consolidated assets of the company and all of its subsidiaries are derived for at least for $85 \%$ from activities that are financial in nature'. See 12 US Code $\$$ 5311. Financial activities include lending, insuring, investment advice and underwriting. See Bank Holding Company Act, section 4(k).

12512 US Code $\S 5323$. The statute does not use the term 'systemically important'. Instead it states that 'material financial distress at the U.S. nonbank financial company, or the nature, scope, size, scale, concentration, interconnectedness, or mix of the activities of the U.S. nonbank financial company, could pose a threat to the financial stability of the United States'. However, in media and literature the term 'systemically important' is commonly used to refer to such a determination.

12612 US Code $\$ 5323(\mathrm{a})(1)$.

${ }^{127}$ Representatives of the insurance industry commenting on the scope and implementation of the determination authority argued, for example, that the 'products and services of regulated, traditional insurance companies are highly substitutable and that these companies operate without significant leverage or reliance on short-term debt and are subject to high levels of existing regulatory scrutiny. Commentators representing the asset management industry contended that asset managers are unlikely to pose a threat to US financial stability, and some noted that the legal distinction between investment advisers and the funds they manage make the prudential standards contemplated by section 165 of the Dodd-Frank Act an inappropriate mechanism for addressing any threat posed by such firms'. See Financial Stability Oversight Council (2012), p. 21638.

${ }^{128}$ Financial Stability Oversight Council (2012), p. 21638. 
Frank Act identified ten factors that the FSOC must consider when determining whether material financial distress at a non-bank financial company could pose a threat to the US economy.

(A) the extent of the leverage of the company;

(B) the extent and nature of the off-balance-sheet exposures of the company;

(C) the extent and nature of the transactions and relationships of the company with other significant non-bank financial companies and significant bank holding companies;

(D) the importance of the company as a source of credit for households, businesses, and State and local governments and as a source of liquidity for the United States financial system;

(E) the importance of the company as a source of credit for low-income, minority, or underserved communities, and the impact that the failure of such company would have on the availability of credit in such communities;

(F) the extent to which assets are managed rather than owned by the company, and the extent to which ownership of assets under management is diffuse;

(G) the nature, scope, size, scale, concentration, interconnectedness, and mix of the activities of the company;

(H) the degree to which the company is already regulated by 1 or more primary financial regulatory agencies;

(I) the amount and nature of the financial assets of the company;

(J) the amount and types of the liabilities of the company, including the degree of reliance on short-term funding; and

(K) any other risk-related factors that the Council deems appropriate.

The FSOC adopted a final rule and interpretive guidance for non-bank financial company determinations, in which it grouped all factors relevant to the risk determination in six categories. ${ }^{129}$ These six categories, referred to as the 'analytic framework for determinations', are: (i) size, (ii) interconnectedness, (iii) substitutability, (iv) leverage, (v) liquidity risk and maturity mismatch, and (vi) existing regulatory scrutiny. Three of these six categories-size, substitutability and interconnectedness-aim to assess the potential impact of the non-bank financial company's financial distress on the broader economy. The purpose of the other three-leverage, liquidity risk and maturity mismatch, and existing regulatory scrutiny of the non-bank financial company-is to assess the vulnerability of a company to financial distress.

In its Rule and Guidance, the FSOC developed a three-stage process for identifying non-bank financial companies for determination under non-emergency situations. ${ }^{130}$ In stage 1 , the FSOC applies six quantitative thresholds to a broad group of non-bank financial companies to identify companies that will be subject to further evaluation by the Council.

\footnotetext{
129 Financial Stability Oversight Council (2012), p. 21641.

130 Financial Stability Oversight Council (2012), pp. 21641-21647.
} 


\subsubsection{Stage 1}

First, a financial company has to have at least $\$ 50$ billion in total consolidated assets. Additionally it has to meet at least one of the following thresholds:

- $\$ 30$ billion in credit default swaps for which the company is the reference entity;

- $\$ 3.5$ billion in derivative liabilities;

- $\$ 20$ billion in total debt outstanding;

- 15 to 1 leverage ratio;

- $10 \%$ short-term debt-to-asset ratio.

Companies that have passed the first stage are subject to active review by the FSOC in stage 2. Additionally, a non-bank financial company which does not meet the thresholds of the first stage may still be subjected to a stage 2 analysis by the FSOC based on other firm-specific qualitative or quantitative factors. After all, the uniform quantitative thresholds may not capture all types of non-bank financial companies and all of the potential ways in which a non-bank financial company could pose a threat to financial stability. ${ }^{131}$

\subsubsection{Stage 2}

In stage 2, the FSOC, conducts a robust analysis of the potential threat that a company could pose to US financial stability. In contrast to the application of uniform criteria under stage 1, stage 2 evaluates the risk profile and characteristics of each individual non-bank financial company. This in line with the belief that systemically important designation cannot be reduced to a formula. ${ }^{132}$ This review is performed on the basis of a company's: (i) size, (ii) interconnectedness, (iii) substitutability, (iv) leverage, (v) liquidity risk and maturity mismatch, and (vi) existing regulatory scrutiny. It is interesting to note that a key factor of the determination is the extent to which the non-bank financial company is subject to regulation. This shows that the designation process actively aims to remedy gaps in regulation and counteracts regulatory arbitrage and thus draws systemically important shadow banks within the regulatory perimeter.

\subsubsection{Stage 3}

Companies that are subsequently advanced to stage 3 are informed through a 'Notice of Consideration' that they are being considered for a 'Proposed Determination'. Review under stage 3 focuses on the non-bank financial company's potential to pose a threat to US financial stability because of the company's material

\footnotetext{
131 Financial Stability Oversight Council (2012), p. 21661.

132 The FSOC further states that '[e]ach determination will be made based on a company-specific evaluation and an application of the standards and considerations set forth in section 113 of the DoddFrank Act, and taking into account qualitative and quantitative information that the Council deems relevant to a particular nonbank financial company'. Financial Stability Oversight Council (2012), p. 21642.
} 
financial distress or the nature, scope, size, scale, concentration, interconnectedness or mix of its activities. The Notice of Consideration will likely include a request for information deemed relevant to the FSOC's evaluation. The information necessary may vary significantly based on the non-bank financial company's business and activities and the information already available. However, the information requests will likely involve both qualitative and quantitative data.

The FSOC indicates that an information request may include confidential business information. ${ }^{133}$ The additional information helps the FSOC to gain a complete image of the systemic risk posed by a company. Factors such the opacity of the non-bank financial company's operations, its complexity, and the extent to which it is subject to existing regulatory scrutiny and the nature of such scrutiny, may not directly cause systemic risks but could mitigate or aggravate them.

Additionally, the FSOC makes an in-depth analysis of the resolvability of the company. This entails assessing the complexity of the non-bank company's legal, funding, and operational structure, and any obstacles to the rapid and orderly resolution of the company.

Based on the analyses conducted in stages 2 and 3, a non-bank financial company may be considered for a Proposed Determination. The FSOC may, by a vote of twothirds of its members (including an affirmative vote of the Council Chairperson), make a Proposed Determination with respect to a non-bank financial company. After the company has been notified of its proposed determination and given the chance to contest it through a non-public hearing, the FSOC will determine by a vote of two-thirds of its voting members whether or not to subject such a company to supervision by the FRB and the prudential standards from Title 1 of the DoddFrank Act.

The FSOC designated American International Group (AIG), General Electric Capital Corporation, Prudential Financial and MetLife to be non-bank financial companies whose material financial distress could pose a threat to US financial stability. Metlife successfully appealed its designation in first instance, with an appeal still pending. ${ }^{134}$ The designation of GE Capital Global Holdings was rescinded by the FSOC on 28 June 2016 after it fundamentally changed its business. ${ }^{135}$ Additionally, the FSOC designated eight financial market utilities as

\footnotetext{
133 Information request may include: 'internal assessments, internal risk management procedures, funding details, counterparty exposure or position data, strategic plans, resolvability, potential acquisitions or dispositions, and other anticipated changes to the non-bank financial company's business or structure that could affect the threat to US financial stability posed by the non-bank financial company'. See Financial Stability Oversight Council (2012), p. 21662.

134 Metlife, Inc. v. Financial Stability Oversight Council, C.A. No. 15-0045 (D.D.C. March 30, 2016).

135 'Since the Council's final determination, GE Capital has fundamentally changed its business. Through a series of divestitures, a transformation of its funding model, and a corporate reorganization, the company has become a much less significant participant in financial markets and the economy. GE Capital has decreased its total assets by over $50 \%$, shifted away from short-term funding, and reduced its interconnectedness with large financial institutions. Further, the company no longer owns any US depository institutions and does not provide financing to consumers or small business customers in the United States'. See Financial Stability Oversight Council (2016), p. 2.
} 
systemically important. Recently, the FSOC started considering asset managers for systemic designation. ${ }^{136}$

\subsubsection{Judicial Protection against Designation}

Following a Proposed Determination, the FSOC provides a written notice of the Proposed Determination to the non-bank financial company. This includes an explanation of the basis of the Proposed Determination. A non-bank financial company that is subject to a Proposed Determination may, within 30 days of receiving any notice of a proposed determination, request a non-public hearing to contest the Proposed Determination. ${ }^{137}$ The FSOC must notify the company of its final determination within 60 days after the hearing.

The company subjected to a final determination may, within 30 days after receiving the notice of final determination, bring an action in the United States district court for the judicial district in which the company's home office is located, or in the United States District Court for the District of Columbia, for an order requiring that the final determination be rescinded. The court's review is limited to determining whether the final determination was arbitrary and capricious.

American insurance company Metlife brought such proceedings before the US District Court of Columbia, complaining inter alia that the FSOC had not followed its own regulations in designating Metlife as a non-bank SIFI and had failed to examine the costs of its designation.

The judicial review by reference to the arbitrary and capricious criterion is narrow as the court is not able to substitute its judgment for that of the agency. ${ }^{138}$ It may only therefore consider "whether the decision was based on a consideration of the relevant factors and whether there has been a clear error of judgment'. ${ }^{139}$ This does mean, however, that the court must consider whether an agency has engaged in reasoned decision-making and has not departed from a prior policy or disregarded its own rules.

Applying this test led the District Court of Colombia to conclude that

FSOC made critical departures from two of the standards it adopted in its Guidance, never explaining such departures or even recognizing them as such. That alone renders FSOC's determination process fatally flawed. Additionally, FSOC purposefully omitted any consideration of the cost of designation to MetLife. Thus, FSOC assumed the upside benefits of designation (even without specific standards from the Federal Reserve) but not the downside costs of its decision. That is arbitrary and capricious under the latest Supreme Court precedent. ${ }^{140}$

\footnotetext{
136 See Wan (2016). However, after the ascension of Trump to the presidency momentum seems to have shifted the other way. See Dizard (2017).

13712 US Code $\S 5325(2)$ and Financial Stability Oversight Council (2012), p. 21662.

138 Motor Vehicle Mfrs. Ass'n of U.S., Inc. v. State Farm Mut.Auto. Ins. Co., 463 US 29, 43 (1983).

139 MetLife, Inc. v. Financial Stability Oversight Council, C.A. No. 150045 (Metlife) citing State Farm, 463 US at 43.

${ }^{140}$ Metlife, at p. 13.
} 
Subsequently, on 30 March 2016, the Supreme Court quashed the FSOC's designation of Metlife as a non-bank SIFI.

\subsection{Supervision of Non-Bank SIFIs}

The Board of Governors of the Federal Reserve System (FRB) is tasked with the primary supervision of systemically important financial institutions. ${ }^{141}$ This includes all bank holding companies with a minimum of $\$ 50$ billion in assets and all non-bank financial companies which have been designated as systemically important by the FSOC. ${ }^{142}$ The FRB is tasked with establishing enhanced prudential standards for non-bank financial companies which are deemed systemically important. $^{143}$

The FRB may establish such enhanced prudential standards on its own initiative or after a recommendation of the FSOC. ${ }^{144}$ The prudential standards developed by the FRB may differentiate between institutions on an individual or categorical basis, thus allowing for the creation of tailored prudential requirements. ${ }^{145}$ The FRB may, therefore, take into consideration the capital structure, riskiness, complexity, financial activities (including the financial activities of their subsidiaries), size, and any other risk-related factors of the financial institution that the FRB deems appropriate. Such a flexible approach to regulation is warranted given the differences in business model and risks between, for instance, insurers and banks. The prudential standards developed by the FRB includes (i) risk-based capital requirements and leverage limits; (ii) liquidity requirements; (iii) overall risk management requirements; (iv) resolution plan and credit exposure report requirements; and (v) concentration limits. ${ }^{146}$

The FRB may establish additional prudential standards for non-bank financial companies that include (i) a contingent capital requirement; (ii) enhanced public disclosures; (iii) short-term debt limits; and (iv) such other prudential standards as the FRB, on its own or pursuant to a recommendation made by the FSOC, determines are appropriate. ${ }^{147}$

In the summer of 2016 the FRB issued an advance notice of proposed rulemaking regarding approaches to regulatory capital requirements for depository institution holding companies significantly engaged in insurance activities, and non-bank financial companies determined by the FSOC that have significant insurance

\footnotetext{
14112 US Code $\$ 5323(\mathrm{a})(1)$ and 12 US Code $\S 5361$.

142 At the time of writing a Systemic Risk Designation Improvement Act of 2016 (Rep. Luetkemeyer, Blaine) has been passed in the House of Representatives and is pending in the Senate. The proposed bill amends the Dodd-Frank Act by providing that the FSOC determination procedure replaces the current process under which bank holding companies with total consolidated assets of $\$ 50$ billion or more are automatically subject to enhanced supervision and prudential standards.

14312 US Code $\$ 5365$.

14412 US Code $\S 5365$ in conjunction with $\S 5325$.

14512 US Code $\$ 5365(2)(\mathrm{A})$.

14612 US Code $\$$ 5365(b)(1)(A).

14712 US Code $\S 5365(\mathrm{~b})(1)(\mathrm{B})$.
} 
activities. $^{148}$ In regard to FSOC designated nonbank financial companies with significant insurance activities_-as discussed these are currently AIG and Prudential Financial — the advanced notice proposes a categorization of the insurance firm's assets and insurance liabilities into risk segments and determine the consolidated required capital by applying risk factors to the amounts in each segment. ${ }^{149}$

\subsubsection{Living Wills}

The Dodd-Frank Act provides that (i) each non-bank financial company designated by the FSOC as systemically important and supervised by the FRB and (ii) bank holding companies with consolidated assets amounting to a minimum of $\$ 50 \mathrm{bn}$, periodically have to provide the FRB, FSOC and the FDIC with a plan for their rapid and orderly resolution in the event of material financial distress or failure. ${ }^{150}$ These resolution plans, commonly known as 'living wills', include:

(A) information regarding the manner and extent to which any insured depository institution affiliated with the company is adequately protected from risks arising from the activities of any non-bank subsidiaries of the company.

(B) full descriptions of the ownership structure, assets, liabilities, and contractual obligations of the company;

(C) identification of the cross-guarantees tied to different securities, identification of major counterparties, and a process for determining to whom the collateral of the company is pledged; and

(D) any other information that the Board of Governors and the Corporation jointly require by rule or order. ${ }^{151}$

On 17 October 2011 the FRB approved a joint rule with the FDIC, implementing the resolution plan requirements of the Dodd-Frank Act. ${ }^{152}$ The rule requires covered firms to perform a strategic analysis of how they can be resolved under the Bankruptcy Code in a way that would not pose systemic risk to the financial system. $^{153}$

A key goal of the actions required in order to prepare a living will is the reduction of the interconnectedness between legal entities within a firm as 'the inability to resolve one legal entity without causing knock-on effects that may propel the failure of other legal entities within the firm makes the orderly resolution of one of these

\footnotetext{
148 Federal Reserve System (2016)

149 Federal Reserve System (2016), p. 38635.

15012 US Code $\S 5365(\mathrm{~d})(1)$.

15112 US Code $\$ 5365(\mathrm{~d})(1)(\mathrm{A})-(\mathrm{D})$.

152 'Resolution Plans Required' (2011) 76 Federal Register 67323, based on Section 165(d) of the DoddFrank Act.

153 The firm must therefore map its core business lines and critical operations, provide integrated analyses of its corporate structure; credit and other exposures; funding, capital, and cash flows; the domestic and foreign jurisdictions in which it operates; and its supporting information systems for core business lines and critical operations.
} 
firms extremely problematic'. ${ }^{154}$ This does not necessarily imply that firms, under the living will obligation, have to break up, but, as Thomas Hoenig, vice chairman of the FDIC put it, 'we want you to structure yourself so that your failure doesn't bring the economy down next time' and 'If you can't get to that point with your current organization structure, then you should sell assets to get to that state'. ${ }^{155}$

Resolution plans will support the FDIC by providing an understanding of the covered companies' structure and complexity as well as their resolution strategies and processes. Additionally, they will assist the FRB in its supervisory task to ensure that covered companies operate in a manner that is both safe and sound and that does not pose risks to financial stability. Finally, the resolution plans enhance the understanding of the US operations of foreign banks resulting in a more comprehensive and coordinated resolution strategy for a cross-border firm. ${ }^{156}$

The living wills are reviewed by the FRB and the FDIC. They may jointly determine that a living will is not credible or would not facilitate an orderly resolution of the company concerned under the Bankruptcy Code. In such a case, the financial institution, after being notified by the FRB and the FDIC, has to resubmit a plan that remedies the deficiencies. If the firm fails to resubmit a credible plan, the FRB and the FDIC may jointly impose restrictions and requirements on the firm or its subsidiaries until it resubmits a plan that remedies the deficiencies. They may require more stringent capital, leverage, or liquidity ratios or restrict growth, activities, or operations. ${ }^{157}$ If the firm fails to resubmit a revised resolution plan within 2 years after being required to fulfil additional requirements, the FRB and the FDIC, in consultation with the FSOC, may jointly order the firm to divest assets or operations to facilitate an orderly resolution under the Bankruptcy Code.

\subsection{Resolution of Non-Bank SIFIs under OLA}

While living wills are intended to identify and remove obstacles to orderly resolution under the Bankruptcy Code, in practice systemically important financial institutions, including bank holding companies, qualify for resolution under the Orderly Liquidation Authority (OLA). ${ }^{158}$

Since the passing of the Dodd-Frank Act, the US has had three main regimes for resolving financial institutions. A general insolvency regime is provided for by the Bankruptcy Code. However, insured depository institutions (i.e. banks) are excluded from the Bankruptcy Code. Instead they are subjected to a specialised regime under federal law. ${ }^{159}$ The Federal Deposit Insurance Company (FDIC) is charged with the application of this regime.

\footnotetext{
154 Gruenberg (2015), p. 6.

155 Moore et al. (2015).

156 Federal Deposit Insurance Corporation (2011b).

15712 US Code $\$ 5384(\mathrm{~d})(5)(\mathrm{A})$.

158 That is not to say that the living wills are not also of value for resolution under the OLA. For example a high degree of interconnectedness within the own organizational structure also impedes resolution under OLA. See Gruenberg (2015).

15912 US Code, $\S 1821,1823$.
} 
The Dodd-Frank Act also established the Orderly Liquidation Authority, which presents an alternative resolution regime for non-bank financial institutions, including bank holding companies. The OLA provide a liquidation regime for covered financial institutions in a manner that mitigates risks to financial stability and minimises moral hazard. ${ }^{160}$ While, in principle, the Bankruptcy Code remains the default option, resolution under the OLA regime is preferred when normal bankruptcy proceedings would potentially harm financial stability.

The OLA applies to financial institutions that are (i) domestic bank holding companies, (ii) non-bank financial companies supervised by the FRB, (iii) any domestic company predominantly engaged in activities that the FRB has determined are financial in nature or incidental thereto, and (iv) any subsidiary of such companies that is predominantly engaged in activities that are financial in nature or incidental thereto (other than a subsidiary that is an insured depository institution or an insurance company). ${ }^{161}$ Consequently, financial institutions that have been designated as systemically important by the FSOC fall within the meaning of 'financial company' under the OLA as they are supervised by the FRB.

Furthermore, in order for a financial company to become 'covered' by the OLA the following conditions must be met: ${ }^{162}$

1. in default or in danger of default;

2. the failure of the financial company and its resolution under otherwise applicable Federal or State law would have serious adverse effects on financial stability in the United States;

3. no viable private sector alternative is available;

4. any effect on the claims or interests of creditors, counterparties, and shareholders of the financial company and other market participants as a result of actions to be taken under this subchapter is appropriate, given the impact that any action taken under this subchapter would have on financial stability in the United States;

5. any action under OLA would avoid or mitigate such adverse effects; ${ }^{163}$

6. a Federal regulatory agency has ordered the financial company to convert all of its convertible debt instruments that are subject to the regulatory order.

These determinations are made by the Secretary of Treasury, acting in consultation with the President and after receiving recommendations from the FRB and the FDIC or (in the case of a broker or dealer) the FRB and the SEC. Pursuant to a determination, a financial company may be placed under OLA in order to liquidate it in a manner that mitigates significant risk to the financial stability of the US and minimises moral hazard.

\footnotetext{
16012 US Code $\$ 5384(\mathrm{~b})$.

16112 US Code $\$ 5381(\mathrm{a})(11)$.

16212 US Code $\$ 5383(\mathrm{~b})$.

163 Therefore the effectiveness of the action in mitigating potential adverse effects on the financial system, the cost to the general fund of the Treasury, and the potential to increase excessive risk-taking on the part of creditors, counterparties, and shareholders in the financial company have to be taken into consideration. See 12 US Code $\S 5383(b)(5)$.
} 
Under an OLA resolution, the FDIC must act as the receiver for the company. It therefore succeeds to all rights and powers of the covered financial company. The FDIC will operate, and conduct all business of, the financial company during its orderly liquidation. It may also appoint itself as receiver of any failing domestic covered subsidiary of the financial company if this would avoid or mitigate adverse effects on the financial stability and such action would facilitate the orderly liquidation of the covered financial company.

\subsubsection{Resolution Under OLA}

With the introduction of OLA, the treatment of qualified financial contracts has been subject to a different treatment than under normal bankruptcy. Qualified financial contracts (QFCs) are any securities contract, commodity contract, forward contract, repurchase agreement and swap agreement, and any agreement deemed similar by the FDIC. ${ }^{164}$ Normally a financial companies' default triggers 'safe harbour' provisions enabling counterparties to terminate derivative contracts and take the collateral. This can accelerate its decline and lead to value destruction, as counterparties race to terminate derivative contracts with the failing institution. ${ }^{165}$

However, under OLA safe harbour provisions, specifically the right to terminate, liquidate or net a QFC may not be exercised during one business day after the FDIC has been appointed receiver. ${ }^{166}$ Furthermore, walkaway clauses-which suspend, condition, or extinguish a payment obligation-are rendered unenforceable. ${ }^{167}$ This gives the FDIC some time to find a third-party buyer for these contracts. According to the FDIC, this provides market certainty and stability and preserves the value represented by the contracts. ${ }^{168}$

A 'top-down' approach to resolution is applied, whereby the top of the financial group (i.e. the parent company level) is placed into receivership and resolution powers are applied by a single resolution authority at this level. The OLA provides the FDIC with the power to merge a company with another company or transfer any asset or liability to another company or a new FSOC-created bridge financial company. ${ }^{169}$ The FDIC does not need to obtain approval for its resolution actions, except approval under antitrust law when it concerns a merger.

\footnotetext{
16412 US Code $\$ 5390(\mathrm{c})(8)(\mathrm{D})(\mathrm{i})$.

165 See Fleming and Sarkar (2014); Scott (2016), p. 215; Schillig (2016), p. 272. The FDIC articulated: 'A complex, systemic financial company can hold very large positions in qualified financial contracts, often involving numerous counterparties and back-to-back trades, some of which may be opaque and incompletely documented. A disorderly unwinding of such contracts triggered by an event of insolvency, as each counterparty races to unwind and cover unhedged positions, can cause a tremendous loss of value, especially if lightly traded collateral covering a trade is sold into an artificially depressed, unstable market. Such disorderly unwinding can have severe negative consequences for the financial company, its creditors, its counterparties, and the financial stability of the United States.' See Federal Deposit Insurance Corporation (2011a), p. 8.

16612 US Code $\$ 5390(\mathrm{c})(10)(\mathrm{B})$.

16712 US Code $\$ 5390(\mathrm{c})(8)(\mathrm{F})$.

168 Federal Deposit Insurance Corporation (2011a), p. 8.

16912 US Code $\$$ 5390(a)(1)(F and G).
} 
Transfer of specific assets and liabilities to a bridge financial company may be used to separate 'good' from 'bad' assets. Assets such as investments in subsidiaries would be transferred to the bridge company. Through capitalisation of the bridge financial company, by issuing new debt and equity or temporary operating funding from the FDIC, ${ }^{170}$ it will be able to provide support to its subsidiaries, thereby ensuring that they can continue operations. The status as bridge company terminates, barring earlier termination, at the latest after 2 years, with the possibility of an extension for no more than three additional one-year periods. ${ }^{171}$

Left behind in the failed parent company are the bad assets together with equity, subordinated debt and senior unsecured debt. Claims against the receivership are paid according to a statutory priority. ${ }^{172}$ At the minimum all creditors must receive at least the amount that they would have received if the FDIC had the company been liquidated under Chapter 7 of the Bankruptcy Code. Creditor's claims in the receivership are satisfied by the issuance of securities representing debt and equity in the new holding company. ${ }^{173}$ Such a securities-for-claims exchange, has the effect of what is commonly referred to as a bail-in and ensures that the new operations are well capitalized. ${ }^{174}$

\subsection{First Experiences with Non-bank SIFI Designation in the US}

As previously mentioned, on 8 July 2013 the FSOC designated American International Group (AIG), General Electric Capital Corporation, Prudential Financial and MetLife as non-bank financial companies which could pose a threat to US financial stability.

After the FSOC's designation of GE Capital, the latter fundamentally changed its business. From being one of the largest financial services companies in the United States and a significant source of credit to the US economy, it decreased its total assets by over 50\%, moved away from short-term funding and reduced its interconnectedness with large financial institutions. ${ }^{175}$ Moreover, it repelled its US depository institutions and no longer provides financing to consumers or small business customers in the United States. As a consequence the FSOC voted on June 28, 2016 to rescind GE Capital's non-bank SIFI designation.

It seems that the FSOC's designation of GE Capital had the positive effect of pulling a shadow banking entity within a suitable regulatory perimeter. Where it had earlier gained an advantage through regulatory arbitrage, this was offset by its designation. In consequence, it had the choice to either compete on a level-playingfield and be subjected to stricter oversight, capital/liquidity requirements, or restructure in such a manner that it no longer posed a systemic risk. GE Capital chose to do the latter. It should therefore be regarded as an early success of the

\footnotetext{
17012 US Code $\$ 5390(\mathrm{~h})(2)(\mathrm{G})$.

17112 US Code $\$ 5390(\mathrm{~h})(12)$.

17212 US Code $\$ 5390(\mathrm{~b})(1)$.

173 Federal Deposit Insurance Corporation (2013), p. 76616.

174 See for a more detailed analyses on bail-in Avgouleas and Goodhart (2015); Schillig (2016).

175 Financial Stability Oversight Council (2016).
} 
Dodd-Franks designation regime as it pulled this shadow banking entity within the regulatory perimeter and effectively alleviated systemic risks.

Metlife's successful appeal of its designation illustrates the importance of an effective judicial appeal possibility. While the authority in charge of designating non-bank SIFIs needs broad discretionary powers to identify and regulate systemic risk, its decisions must adhere to general principles of law in order to avoid the appearance of arbitrary decision-making.

In regard to future developments, it is interesting to note that the FSOC has adopted an open approach in order to address systemic risk wherever it might arise. Treasury Secretary Jacob J. Lew emphasised in a Wall Street Journal op-ed that 'It is particularly important that FSOC look over the horizon to where future risks may develop'. ${ }^{176}$ Interestingly, the FSOC is now in the process of examining whether asset managers might present risks that could threaten financial stability. ${ }^{177}$ However, as stated previously, the Trump administration seems to prefer light-touch regulation. ${ }^{178}$

\section{Policy Response in the EU}

As discussed in the previous section, the FSOC's powers to designate a non-bank institution as systemically important and the possibility to liquidate financial institutions under the OLA mark the adoption of a more holistic approach to the identification and mitigation of the systemic risks posed by non-bank SIFIs. In the EU, the policy response to the global financial crisis and the European sovereign debt crisis has remained organised largely along sectoral lines. The most notable reform has been the creation of a European Banking Union (EBU) which entailed an extensive overhaul and transfer of bank supervision and resolution to the EU level. ${ }^{179}$ Because the creation of the Banking Union is the single most important response to the manifestation of systemic risk in the eurozone, a short account of its institutional make-up and scope, especially in relation to shadow banking entities, is in order. This will also allow us to assess the feasibility of expanding its scope to capture systemically important shadow banking entities.

\subsection{The European Banking Union}

The European focus on the banks can be understood against the backdrop of the euro specific sovereign debt crisis. European governments were confronted with banks that held more debt on their balance-sheets than their gross domestic product (GDP). Large-scale government bailouts created a colossal financial burden,

\footnotetext{
176 Lew (2016).

177 Lew (2016).

178 Dizard (2017).

179 On EBU, see, for example, Busch and Ferrarini (2015).
} 
consequently propelling debt-to-GDP ratios. ${ }^{180}$ As European banks are prone to hold large amounts of debt from their national governments, any deterioration of the state's financial position consequently erodes banks' solvency and vice versa. Lacking a supranational resolution framework and a common fiscal backstop, states remained individually responsible for bailing-out banks headquartered in their territory. ${ }^{181}$ This burdened their finances, leading to stress on the sovereign-bond markets which, in turn, led to a deterioration in the value of the bank's assets. ${ }^{182}$ At the same time, indebted governments came to rely even more on financing from domestic banks. ${ }^{183}$ This has created an interdependence between the two, with any deterioration of the one impairing the position of the other, a situation ominously referred to as the bank-sovereign 'doom loop'. ${ }^{184}$

Consequently, a credible resolution framework for banks is crucial in order to provide a viable alternative to bailouts and a cross-border distribution of related costs. Indeed, shifting the burden of failing banks away from national budgets to the European level is often cited as the true raison d'etre of the European Banking Union (EBU). ${ }^{185}$ Such a regime would, together with European supervision of the largest banks, help to break the feedback loop between sovereigns and banks. Ideally, it should also do so by providing a credible alternative to the dreaded, public-funded, bailouts. It is therefore no surprise that the Euro Area Summit Statement of 29 June 2012 proclaimed 'that it is imperative to break the vicious circle between banks and sovereigns'. In the same statement, the Commission was tasked with presenting 'proposals on the basis of Article 127(6) for a single supervisory mechanism'. 186

\footnotetext{
${ }_{180}$ A striking example is Ireland which had a mere 25\% debt-to-GDP ratio at the end of 2007, but had to apply for joint EU/IMF financial assistance after the process of bailing outs its banks had increased its debt-to-GDP to $108 \%$. See Pisani-Ferry (2012), p. 6.

181 While States were individually responsible, cross-border contagion risks posed by failing banks led to international pressure to provide bailouts. See Lane (2012), p. 59.

182 For a more elaborate analysis of the bank-sovereign doom loop, see Merler and Pisani-Ferry (2012); Véron (2015).

183 The origin of the European Banking Union lies in the occurrence of the bank-sovereign loop in Spain in 2012. The deteriorating state of banks in Spain eventually led the government to request financial assistance. Spain, Italy and France, backed by EU institutions, pushed for direct recapitalisation of the banks through the European Stability Mechanism (ESM). By recapitalising the banks directly instead of transmitting the assistance through the Spanish Treasury, it would be possible to avoid creating a further debt burden for the Spanish budget. Germany, which was hesitant about the idea of refinancing banks over which it had no control, demanded centralised European banking supervision in exchange for direct ESM recapitalisation. This led to the euro area summit statement of 29 June 2012 pronouncing that it is imperative to break the vicious circle between banks and sovereigns. When an effective single supervisory mechanism is established, involving the ECB, for banks in the euro area the ESM could, following a regular decision, have the possibility to recapitalize banks directly'.

${ }^{184}$ As Martin Wolf pungently remarked 'Stressed banks and weak sovereigns behaved like two drunks trying to hold each other up'. See Wolf (2014), pp. 56-57.

185 Moloney (2014b), p. 1624. The European Parliament stated that 'breaking up the negative feedback loops between sovereigns, banks and the real economy is crucial for a smooth functioning of the EMU' and 'requires the realisation of a fully operational European Banking Union'. See European Parliament (2012).
}

${ }^{186}$ Euro Area Summit Statement, Brussels, 29 June 2012. 


\subsubsection{Scope of the Single Supervisory Mechanism}

The first pillar of the European Banking Union is the Single Supervisory Mechanism. ${ }^{187}$ It should be noted that the SSM is a mechanism not a supervisory entity. ${ }^{188}$ It is not an agency, nor does it have legal personality. At its heart lies the $\mathrm{ECB}$, which is directly responsible for the prudential supervision of significant credit institutions and for the effective and consistent functioning of the SSM. ${ }^{189}$ National authorities remain primarily responsible for the supervision of less significant credit institutions.

The scope of the SSM is limited to the prudential supervision of credit institutions, financial holding companies and, subject to certain conditions, mixed financial holding companies. ${ }^{190}$ Additionally, branches established in participating Member States of credit institutions established in non-participating Member States are included in the SSM supervision. ${ }^{191}$

For a definition of 'credit institution' the SSM Regulation refers to the Capital Requirement Regulation (CRR). According to the CRR definition a credit institution is 'an undertaking the business of which is to take deposits or other repayable funds from the public and to grant credits for its own account'. ${ }^{192}$ The key terms 'deposits', 'other repayable funds', 'from the public' and 'grant credits' are not defined in the CRR. Nor is there any uniform approach to 'credit institution' in the Member States. Consequently, the interpretation of credit institution may differ from one Member State to another. ${ }^{193}$ As long ago as 2009, the de Larosière Report pointed out that differences in the definition of credit institutions are a source of problematic divergences between members that can lead to laxer supervision and regulatory arbitrage. This problem has also been noted by the Commission, which has tasked the European Banking Authority (EBA) with giving an opinion on the

\footnotetext{
187 Established by Council Regulation (EU) No. 1024/2013 of 15 October 2013 conferring specific tasks on the European Central Bank concerning policies relating to the prudential supervision of credit institutions [2013] OJ L287.

188 Art. 2(9) SSM Regulation defines the SSM as 'the system of financial supervision composed by the ECB and national competent authorities of participating Member States'.

189 SSM Regulation, Art. 6(1).

190 A mixed financial holding company is defined as a parent undertaking, other than a regulated entity, which together with its subsidiaries, at least one of which is a regulated entity which has its head office in the Community, and other entities, constitutes a financial conglomerate (Art. 2(5) SSMR in conjunction with Art. 4(1) CRR in conjunction with Art. 2 of Directive 2002/87/EC (the Financial Conglomerates Directive)). A mixed financial holding company falls under the supervisory scope of the SSM when the coordinator of the financial conglomerate (as provided by Directive 2002/87/EC) is an authority competent for the supervision of credit institutions and is also the coordinator in its function as supervisor of credit institutions (Art. 2(21)(b) SSM Framework Regulation).

191 SSM Regulation. Art. 6(4).

192 CRR Art. 4(1) sub 1.

193 The European definition indicates that an undertaking has to receive deposits in order to qualify as a credit institution. This is not necessarily a requisite under national law. It follows that certain undertakings which would qualify as credit institution under national law will not be regarded as such under the European regime.
} 
perimeter of 'credit institution'. It is hoped that this opinion will lead to a delegated act of the Commission defining the exact perimeter of credit institutions. ${ }^{194}$

Other financial institutions are, explicitly or implicitly, beyond the scope of application of the SSM. As made clear by Article 127(6) of the Treaty on the Functioning of the European Union (TFEU), insurance undertakings are in any event excluded from the SSM. Central Clearing Counterparties (CCPs) are likewise excluded from the SSM if they do not also qualify as credit institution. ${ }^{195}$ Other market infrastructure facilities such as multilateral trading facilities only fall under the SSM regime when they also participate in banking activities.

The exclusion of market infrastructure, insurers, investment firms and other shadow banking entities is puzzling from the perspective of financial stability. The global financial crisis clearly demonstrated their potential to pose a threat to the stability of the financial system. ${ }^{196}$ The limited scope of the Banking Union appears to be primarily motivated by legal limitations and policy makers' priority of breaking the vicious circle between banks and sovereigns. ${ }^{197}$ Legal limitations arise from Article 127(6) TFEU, which allows for the conferral of specific tasks upon the European Central Bank concerning policies relating to the prudential supervision of credit institutions and other financial institutions, with the explicit exception of insurance undertakings.

However, non-bank financial institutions are not completely unaffected by supervision under the SSM. The ECB is charged with supervision on a consolidated basis of credit institutions, financial holding companies and mixed financial holding companies that are significant on a consolidated basis, where the parent undertaking is an EU parent institution established in a participating Member State. ${ }^{198}$ As consolidated supervisor and in cooperation with the supervisor of subsidiaries, it has to reach a joint decision on the adequacy of the consolidated level of own funds and liquidity requirements. ${ }^{199}$

A financial holding company is a financial institution ${ }^{200}$ the subsidiaries of which are exclusively or mainly institutions (i.e. credit institutions or investment firms) ${ }^{201}$ or financial institutions, at least one of such subsidiaries being an institution, and which is not a mixed financial holding company. A mixed financial holding

\footnotetext{
194 European Banking Authority (2014).

195 SSM Regulation, Art. 1.

196 See also: Wymeersch (2014), p. 29; Ferran and Babis (2013), p. 5.

197 Ferran and Babis (2013), p. 5.

198 SSM Regulation, Art. 4(1)(g) in conjunction with SSM Framework regulation, Art. 8.

199 CRD IV, Art. 113(1)(a) and (b).

200 'Financial institution' means an undertaking other than an institution, the principal activity of which is to acquire holdings or to pursue one or more of the activities listed in points 2 to 12 and point 15 of Annex I to Directive 2013/36/EU, including a financial holding company, a mixed financial holding company, a payment institution within the meaning of Directive 2007/64/EC of the European Parliament and of the Council of 13 November 2007 on payment services in the internal market (1), and an asset management company, but excluding insurance holding companies and mixed-activity insurance holding companies as defined in point (g) of Art. 212(1) of Directive 2009/138/E. See CRR, Art. 3(26).

201 'Institution' means a credit institution or an investment firm. See CRR, Art. 3(3).
} 
company means a parent undertaking, other than a regulated entity, ${ }^{202}$ which, together with its subsidiaries - at least one of which is a regulated entity which has its registered office in the Union-and other entities, constitutes a financial conglomerate. $^{203}$

\subsubsection{Scope of the Single Resolution Mechanism}

The second pillar of the European Banking Union constitutes the Single Resolution Mechanism (SRM). ${ }^{204}$ The SRM became fully operational on 1 January 2016 and provides for a resolution regime for banks. It places the Single Resolution Board, a newly created European agency, in charge of the decision-making on bank resolution.

Within the SRM the tasks are divided between the SRB and the national resolution authorities (NRAs). The latter are directly responsible for the resolution of non-significant entities ${ }^{205}$ and non-cross-border entities and groups. The NRAs are, however, bound to apply the resolution tools referred to in the SRM Regulation. $^{206}$ To this end, the NRAs must apply resolution powers conferred on them under national law transposing the BRRD, in accordance with the conditions laid down in national law. ${ }^{207}$ It should be pointed out that, in so far as this may lead to differences in the application of the resolution tools, for example due to divergent

\footnotetext{
202 'Regulated entity' means a credit institution, an insurance undertaking, a reinsurance undertaking, an investment firm, an asset management company or an alternative investment fund manager. See the Financial Conglomerates Directive, Art. 2(4).

203 'Financial conglomerate' means a group or subgroup, where a regulated entity is at the head of the group or subgroup, or where at least one of the subsidiaries in that group or subgroup is a regulated entity, and which meets the following conditions:

(a) where there is a regulated entity at the head of the group or subgroup:

(i) that entity is a parent undertaking of an entity in the financial sector, an entity which holds a participation in an entity in the financial sector, or an entity linked with an entity in the financial sector by a relationship within the meaning of Art. 12(1) of Directive 83/349/EEC;

(ii) at least one of the entities in the group or subgroup is within the insurance sector and at least one is within the banking or investment services sector; and

(iii) the consolidated or aggregated activities of the entities in the group or subgroup within the insurance sector and of the entities within the banking and investment services sector are both significant within the meaning of Art. 3(2) or (3) of this Directive; or

(b) where there is no regulated entity at the head of the group or subgroup:

(i) the group's or subgroup's activities occur mainly in the financial sector within the meaning of Art. 3(1) of this Directive;

(ii) at least one of the entities in the group or subgroup is within the insurance sector and at least one is within the banking or investment services sector; and

(iii) the consolidated or aggregated activities of the entities in the group or subgroup within the insurance sector and of the entities within the banking and investment services sector are both significant within the meaning of Art. 3(2) or (3) of this Directive.

204 Established by Regulation (EU) No. 806/2014 of the European Parliament and of the Council of 15 July 2014 establishing uniform rules and a uniform procedure for the resolution of credit institutions and certain investment firms in the framework of a Single Resolution Mechanism and a Single Resolution Fund and amending Regulation (EU) No. 1093/2010 [2014] OJ L225.

205 Following the determination of the ECB in accordance with SSM Regulation, Art. 6(4).

206 SRM Regulation, Art. 7(3) sub (e).

207 SRM Regulation, Art. 7(3), fourth paragraph.
} 
national implementations of the BRRD, the SRB remains responsible for the uniform and consistent application and may intervene accordingly. ${ }^{208}$ Consequently, they do not have additional resolution powers granted under national legislation. ${ }^{209}$

The SRM covers all credit institutions established in participating Member States, regardless of their size. ${ }^{210}$ Also within the scope of resolution under the SRM are (i) parent undertakings subjected to consolidated supervision by the ECB, and (ii) investment firms ${ }^{211}$ and financial institutions, established in a participating Member State, that are covered by the ECB's consolidated supervision of the parent. $^{212}$ These entities are brought within the scope of the SRM because-to the extent that parent undertakings, investment firms and financial institutions are included in the consolidated supervision by the ECB - the ECB will be the only supervisor that has a global perception of the risk to which a group (and indirectly its individual members) is exposed-even if it does not supervise these entities on a solo basis. ${ }^{213}$

Resolution of a parent undertaking can take place when:

(i) the resolution conditions ${ }^{214}$ are met with regard to both the financial institution and with regard to the parent undertaking subject to consolidating supervision;

(ii) the resolution conditions are met with regard to both the parent undertaking and with regard to one or more subsidiaries which are institutions (i.e. credit institutions or investment firms); ${ }^{215}$

(iii) a subsidiary which is an institution meets the resolution conditions and its assets and liabilities are such that its failure threatens an institution or the group as a whole and resolution action with regard to that parent undertaking is necessary for the resolution of such subsidiaries which are institutions or for the resolution of the group as a whole;

(iv) the insolvency law of the Member State provides that groups be treated as a whole and resolution action with regard to the parent undertaking is

\footnotetext{
208 The SRB may issue a warning to an NCA or even decide to take over its tasks. See SRM Regulation, Art. 7(4) sub (a) and (b).

209 See Busch et al. (2018b).

210 SRM Regulation, Art. 2.

211 Covered investment firms are those subjected to the initial capital requirement of EUR 730,000. See SRM, Art. 3(2) in conjunction with BRRD, Art. 2(3) in conjunction with CRR, Art. 4(1) in conjunction with CRD IV, Art. 28.

212 SRM Regulation, Art. 2

213 SRM, recital 22.

214 The resolution conditions are: (a) the entity is failing or is likely to fail; (b) having regard to timing and other relevant circumstances, there is no reasonable prospect that any alternative private sector measures, including measures by an institutional protection scheme, or supervisory action, including early intervention measures or the write-down or conversion of relevant capital instruments, would prevent its failure within a reasonable timeframe; (c) a resolution action is necessary in the public interest. See SRM, Art. 18.

215 'Institution' means a credit institution or an investment firm. See CRR, Art. 3(3).
} 
necessary for the resolution of such subsidiaries which are institutions or for the resolution of the group as a whole. ${ }^{216}$

Consequently, resolution primarily focuses on and applies to credit institutions or 730k investment firms covered by consolidated supervision of the ECB. However, when the parent undertaking also meets the conditions for resolution or when economic interdependencies are such that failure of a subsidiary threatens the group as a whole, the parent can be pulled into resolution along with its subsidiary institution. At the same time, group resolution extends only to credit undertakings, parent undertakings subject to consolidated supervision of the ECB, and investment firms and financial institutions covered by the consolidated supervision of the parent undertaking (SRM entities). Other institutions within the same group are left outside the scope of resolution. Similarly, a failing subsidiary, for example an insurance undertaking, cannot trigger resolution of the group.

\subsubsection{Conclusions on the Scope of the Banking Union}

The Banking Union is first and foremost a mechanism which provides for the supervision and resolution of banks within the eurozone. However, its scope does extend to certain non-bank entities and groups. The SSM also captures parent undertakings which are a financial holding or mixed financial holding. The resolution mechanism also extends to $730 \mathrm{k}$ investment firms and financial institutions that are covered by the consolidated supervision of the parent undertaking by the ECB.

This creates a complicated legal patchwork where certain non-bank financial entities are also affected by the regime created by the Banking Union. Whether and, if so, to what extent an entity falls within the scope of the Banking Union depends on its legal classification (e.g. the perimeter or definition of credit institution) and the nature of the group to which it belongs.

The partial supervision of financial groups, which excludes solo supervision of non-bank entities within a group, but includes supervision of their parent holding, risks gaps in supervision. Similarly, resolution at group level can be triggered only if strict conditions are met, with the health of the group's bank subsidiary being decisive. This could encourage regulatory arbitrage activities as groups might escape supervision and resolution under the Banking Union by changing the makeup of their group.

Although the Banking Union is an ambitious and vigorous overhaul of banking supervision in the eurozone, it risks being inflexible and setting a non-future proof regulatory perimeter due to the rigid scope of its application. ${ }^{217}$

\footnotetext{
216 SRM, Art. 16.

217 Posen and Véron also note that 'The exclusion of smaller banks and non-banks from direct supervision at European level could lead to harmful regulatory arbitrage'. See Posen and Véron (2014).
} 


\subsection{Other Sectoral Reform in the EU}

Besides the European Banking Union, the European legislators have adopted numerous reform measures for the financial sector. ${ }^{218}$ These can largely be divided into regulation, either of markets or financial institutions, and supervisory infrastructure. Both are organised mainly along sectoral lines.

\subsubsection{Regulatory Reforms}

Many of the regulatory reforms have, at least partially, a financial stability objective. This reduces the potential for regulatory arbitrage, at least in regard to the applicable entities. For instance, investment funds are subject to increased regulation under the 'undertakings for collective investment in transferable securities' (UCITS) Directive ${ }^{219}$ or the Alternative Investment Fund Managers Directive (AIFMD) ${ }^{220}$ Both directives have the effect of reducing liquidity risks in investment funds. The UCITS Directive requires investment funds to hold liquid assets only. Alternative investment funds (AIFs), other than unleveraged closedended AIFs, must employ appropriate liquidity management and monitoring procedures for liquidity risks. ${ }^{221}$ The liquidity profile of the investments must comply with the AIF's underlying obligations.

The UCITS Directive places direct restrictions on the use of leverage. A UCITS may only borrow up to $10 \%$ of its assets. ${ }^{222}$ Additionally, synthetic leverage, which is acquired through derivatives and securities lending and measured in 'global exposure', must not exceed the fund's total net asset value. ${ }^{223}$ The AIFMD, in contrast, does not provide regulatory limits on the amount of leverage. Instead, the

\footnotetext{
218 For an overview of the more than 40 European Commission proposals for legislative and nonlegislative measures, see https://ec.europa.eu/info/business-economy-euro/banking-and-finance/financialreforms-and-their-progress/progress-financial-reforms_en (last visited on 17 July 2017).

219 This directive concerns EU-based, open-ended collective investment arrangements which invest in a diverse portfolio of transferable securities or specific other liquid financial assets and offers participation to the public. See Directive 2009/65/EC of the European Parliament and of the Council of 13 July 2009 on the coordination of laws, regulations and administrative provisions relating to undertakings for collective investment in transferable securities [2009] OJ L302/32, Arts. 1 and 3(b).

220 AIFs are collective investment undertakings which are offered to a number of investors and invest their collective assets in accordance with a defined investment policy without requiring authorisation as a UCITS. This broad definition captures all non-UCITS. See Directive 2011/61/EU of the European Parliament and of the Council of 8 June 2011 on Alternative Investment Fund Managers and amending Directives 2003/41/EC and 2009/65/EC and Regulations (EC) No. 1060/2009 and (EU) No. 1095/2010 [2011] OJ L174/1, Art. 4(a). For a detailed discussion of the AIFMD, see van Setten and Busch (2014); Zetzsche (2015).

221 AIFMD, Art. 16.

222 UCITS Directive, Art. 83.

223 UCITS Directive, Art. 51(3). Global exposure can be calculated according to the standard 'commitment approach', in which case a total market exposure of $200 \%$ of NAV is permitted. Alternatively, global exposure may be calculated according to the value-at-risk model. This model is recommended by ESMA for funds with more complex investment strategies. Under this model the total value-at-risk has to stay below $20 \%$ of the net asset value, which potentially allows for more leverage.
} 
AIFM has to demonstrate the leverage limits set by it, for each AIF it manages, are reasonable and that it complies with them at all times. National authorities are competent to impose leverage limits on an AIF in its jurisdiction where they deem this necessary in order to ensure the stability and integrity of the financial system. ${ }^{224}$ Furthermore, additional regulation is applicable to money-market funds to preserve the integrity and stability of the internal market. ${ }^{225}$

In regard to the insurance sector, the EU legislator adopted the Solvency II Directive, harmonising EU insurance regulation. ${ }^{226}$ The Solvency II Directive requires Member States to ensure that their supervisory authorities can protect policyholders and, second, to contribute to the stability of the financial system as a whole. $^{227}$ Solvency II therefore requires insurers and regulators to take account of the asset-side risks, as capital needs to be held against market risks.

However, notwithstanding the increase in sector regulation, the potential for regulatory arbitrage remains. The ESRB, for instance, notes in its 2017 shadow banking report that hedge funds should be closely monitored as they are not subject to leverage limits if regulated under the AIFMD. ${ }^{228}$ More importantly, such an approach to financial regulation remains calibrated on 'form over function'; in other words, the legal label of a financial institution is decisive for the applicable regulation and supervisor. In consequence, new financial market participants (e.g. FinTech entities) or formally different institutions performing similar activities may fall into regulatory gaps. ${ }^{229}$

\footnotetext{
224 AIFMD, Art. 25(3).

225 The regulation allows for constant net asset value (CNAV) for short-term MMFs investing in government debt. A new category is introduced as low volatility net asset value (LVNAV), which may maintain a constant NAV within certain perimeters. All other MMFs have to convert into variable net asset value (VNAV). The regulation also introduced liquidity requirements: CNAC and LVNAV must have $10 \%$ of NAV daily maturing and $30 \%$ of NAV weekly maturing. For VNAV funds these percentages are 7.5 and 15.5 respectively. See Regulation (EU) 2017/1131 of the European Parliament and of the Council of 14 June 2017 on money market funds (Text with EEA relevance) [2017] OJ L169.

${ }^{226}$ Directive 2009/138/EC of the European Parliament and of the Council of 25 November 2009 on the taking-up and pursuit of the business of Insurance and Reinsurance (Solvency II) [2009] OJ L335.

${ }^{227}$ Everson (2015), p. 433.

${ }^{228}$ European Systemic Risk Board (2017), p. 18. For a discussion of the macroprudential elements and gaps in existing EU regulation, see European Systemic Risk Board (2016b).

${ }^{229}$ Recent examples of different institutions performing functionally equivalent services are inter alia apparent from ABN AMRO's prospectus. Risk factor 8 notes that ABN AMRO's competition for products and services 'consists of traditional large banks, smaller banks, insurance companies, pension funds, niche players, nonfinancial companies that offer credit and savings products (such as car lease companies) as well as technology firms and other new entrants. Insurance companies and pension funds, for instance, are increasingly active in the mortgage market. Not all of these parties are subject to the same regulatory controls imposed on banks.' See ABN AMRO (2015), p. 78.

ESMA also finds that the evolving loan origination by investment funds, has the potential for additional systemic risks. ESMA therefore argues that it should fall under a suitable regulatory framework such that 'systemic risk is mitigated, and, in any case, is no higher than that posed by bank lending'. More specifically, regulation should mitigate risks stemming from liquidity and maturity transformation and risks related to imprudent lending. See ESMA (2016)
} 


\subsubsection{The European Supervisory Agencies}

The institutional supervisory structure provided at EU level mimics the sectoral approach in regulation. The previous structure of informal cooperation and peer review arrangement at EU level, provided for in the form of the Lamfalussy Level 3 committees, have been replaced by more robust European Supervisory Agencies (ESAs). The tasks of the ESAs are delineated along sectoral, institutional lines. The ESAs consist of the European Banking Authority (EBA), the European Securities and Markets Authority (ESMA) and the European Insurance and Occupational Pensions Authority (EIOPA). They have a dual function of harmonisation and identification of (macro) prudential risks. To this end, they draft technical standards and guidelines which are endorsed and adopted by the European Commission. ${ }^{230}$ Of the three ESAs, currently only ESMA has direct supervisory powers over Credit Rating Agencies and Trade Repositories. ${ }^{231}$

The governance set-up of the ESAs is, however, such that national interests are still predominant, hindering the exercise of powers in the common interests of the EU. The Board of Supervisors is the main decision-making body of each of the ESAs. The Board of Supervisors of each ESA is composed of (i) the chairperson, who has no voting rights, (ii) the heads of the national competent authorities (NCAs), all of whom have voting rights. There is also one representative each from (a) the Commission, (b) the ESRB, (c) the two other ESAs and (d) in the case of EBA, the ECB is represented. None of them has voting rights. ${ }^{232}$ As the Commission observes in its 'Public consultation on the operations of the European Supervisory Authorities' of 21 March 2017: ${ }^{233}$ 'Experience has shown that, depending on the circumstances, this configuration may lead to conflicts of interests and may fail to deliver solutions and decisions in the best interest of the EU as a whole. $^{234}$

It is interesting to note that the Commission, in its ESA consultation document, stated that a careful reflection about supervisory arrangements is in order, especially against the backdrop of a developing Capital Markets Union and the UK's vote to leave the EU. Amongst other things, the Commission asked for views to help identifying specific areas where stronger European supervision would provide clear

\footnotetext{
${ }^{230}$ This is related to the legal constraints on EU agencies pursuant to the Meroni doctrine. See infra Sect. 6.3.1.

${ }^{231}$ EMSA supervision of credit rating agencies is established in Regulation (EU) No. 462/2013 of the European Parliament and of the Council of 21 May 2013 amending Regulation (EC) No. 1060/2009 on credit rating agencies [2013] OJ L146. Supervision of trade repositories in Regulation (EU) No. 648/2012 of the European Parliament and of the Council of 4 July 2012 on OTC derivatives, central counterparties and trade repositories [2012] OJ L201. In exceptional cases, where the national competent authority does not comply with a decision or formal opinion of an ESA and this is necessary for the orderly functioning and integrity of financial markets or the stability of the whole or part of the financial system in the Union, the ESA may adopt decisions addressed directly to a financial institution. See Arts. 17(6) and 18(4) of the respective ESA Regulations.

${ }^{232}$ See ESMA Regulation and EIOPA Regulation, each time at Art. 40(1)(c), (d) and (e). See EBA Regulation, at Art. 40(1)(c), (d), (e) and (f).

${ }^{233}$ European Commission (2017).

${ }^{234}$ See European Commission (2017), pp. 18-19.
} 
added value to overcome market fragmentation and to develop integrated capital markets, so as to ensure that risks are being appropriately regulated and supervised. ${ }^{235}$ The Commission is therefore considering a possible extension of ESMA's powers in the following areas: (1) in market segments in which there is a strong need to support more integrated, efficient and well-functioning financial instruments markets, (2) in areas where common solutions in the application of the EU capital market rules are more efficient ${ }^{236}$ or (3) in areas where high integration or intense cross-border activity entails higher cross-border contagion risks to financial stability or market integrity. ${ }^{237}$ The Commission provides three examples for a possible extension of ESMA's current mandate: (i) direct supervision of data providers, (ii) direct supervision of the asset management industry and (iii) direct supervision of central counterparties (CCPs).

In regard to the latter, the Commission published, on 13 June 2017, proposed amendments to the European Market Infrastructure Regulation (EMIR) and the ESMA Regulation, with a view to regulating and supervising the systemic risk posed by CCPs and strengthening the role of ESMA. ${ }^{238}$ In order to avoid risks of regulatory and supervisory arbitrage the 'CCP executive session'-established within the European Securities and Markets Authority (ESMA)—will be responsible for a more coherent and consistent supervision of CCPs. To this effect, ESMA may determine a third-country CCP to be systemically important, thereby subjecting it to stricter requirements. Acting on a recommendation from ESMA, the Commission may also determine a third-country CCP to be substantially systemically important. Subsequent to such a determination, the Commission may declare that the CCP may provide services in the Union only if it is authorised in the EU. ${ }^{239}$ The determination of systemic importance of CCPs by ESMA shows clear parallels with our proposed non-bank SIFI determination.

In conclusion, two elements in the make-up of the European Supervisory Agencies stand out. First, despite some coordination efforts, it is based on a sectoral approach to supervision. ${ }^{240}$ As sectoral lines increasingly blur and new institutions

\footnotetext{
235 European Commission (2017), pp. 16-17.

236 The Commission finds that this might, for example, be due to synergies or to more uniform application of rules leading to less obstacles for market integration and less opportunities for companies to take advantage of loopholes in order to avoid unprofitable regulations or for regulators to compete with one another in order to attract businesses or other actors to operate in their jurisdiction. See European Commission (2017), p. 17. These objectives are in line with our proposal.

237 European Commission (2017), p. 17.

238 European Commission, Proposal for a Regulation of the European Parliament and of the Council amending Regulation (EU) No. 1095 and amending Regulation (EU) No. 648/2012, COM(2017) 331 final (13 June 2017) (EMIR Commission Proposal 13 June 2017). Recognising the central and growing systemic importance of CCPs as a result of the G20 commitment to clear additional classes of over-thecounter derivatives with CCPs, the Commission previously proposed recovery and resolution measures for CCPs in order to safeguard financial stability. See European Commission, Proposal for a regulation of the European Parliament and of the Council on a framework for the recovery and resolution of central counterparties and amending Regulations (EU) No. 1095/2010, (EU) No. 648/2012, and (EU) 2015/2365, COM(2016) 856 final (28 November 2016).

239 For the role for ESMA with regard to EU CCPs, see Busch (2018).

240 See also Awrey (2016), p. 86.
} 
outside the traditional institutional regulatory perimeter perform equivalent activities, an institutionally based layout of the supervisory organisation may risk regulatory gaps. As illustrated by the crisis and described in Sect. 2, an institutional approach to financial regulation and supervision encourages regulatory arbitrage. It is therefore of eminent importance that an institutional approach to financial regulation is supplemented by the existence of an authority with robust, financial sector-wide, monitoring powers and, if deemed necessary, the power to pull systemically important financial institutions inside a suitable regulatory and supervisory perimeter. As discussed in the following section, the European Systemic Risk Board is responsible for monitoring the financial system within the EU and identifying systemic risk. Its powers, however, are rather limited.

A second important element in the functioning of the ESAs is their limited powers of direct prudential supervision of financial institutions. ${ }^{241}$ Instead, national authorities are responsible for day-to-day prudential supervision. Systemically important institutions expand, however, across many jurisdictions. Much the same arguments that underpin the creation of direct ECB supervision over significant credit institutions therefore apply also to non-bank SIFIs. This line of reasoning is now familiar, for example because a European authority is better placed to ensure a smooth and sound overview of the entire non-bank SIFI and its overall health and would reduce the risk of different interpretations and contradictory decisions at the level of the individual entity, thereby enhancing market integration. In our proposal, designated non-bank SIFIs, like significant credit institutions, should therefore be placed under direct prudential supervision by an EU authority. The intended reforms of the ESAs may therefore provide a connection with our proposal. They illustrate a developing inclination to endow the ESAs with more direct supervisory powers. Supervision of designated non-bank SIFIs by the most relevant ESA, as determined by the nature and activities of the non-bank SIFI, is in line with these developments.

\subsection{Systemic Risk Monitoring by the European Systemic Risk Board}

The de Larosière Group envisaged a Union body charged with overseeing risk in the financial system as a whole. ${ }^{242}$ This led to the creation, in November 2010, of the European Systemic Risk Board (ESRB). ${ }^{243}$ It is tasked with exercising 'macroprudential oversight of the financial system within the Union, in order to contribute to the prevention or mitigation of systemic risks to financial stability in the Union'. ${ }^{244}$ Its oversight has a broad scope as the ESRB Regulation recognises that all types of

\footnotetext{
241 As stated, only ESMA performs direct supervision, namely of credit rating agencies, trade repositories and, if the Commission's legislative proposal is accepted, CCPs.

242 'The Group believes that to be effective macro-prudential supervision must encompass all sectors of finance and not be confined to banks, as well as the wider macro-economic context. This oversight also should take account of global issues.' See de Larosière et al. (2009), p. 39.

243 Regulation (EU) No. 1092/2010 on European Union macro-prudential oversight of the financial system and establishing a European Systemic Risk Board [2010] OJ L331 (ESRB Regulation).

244 ESRB Regulation, Art. 3(1).
} 
financial intermediaries, markets and infrastructure may potentially be systemically important to some degree. ${ }^{245}$

As a consequence of the global financial crisis, microprudential supervision of financial institutions has become increasingly complemented by a macroprudential dimension. The latter's objective is to limit the distress of the financial system as a whole in order to protect the overall economy from significant losses in real output. ${ }^{246}$ Macroprudential supervision focuses on systemic risks arising from the common exposure of many financial institutions to the same risk factors. In other words, whereas microprudential supervision focuses on the tree, macroprudential supervision is all about the forest. ${ }^{247}$ In accordance with its macroprudential tasks, the ESRB monitors and assesses risks and, if necessary, adopts warnings and recommendations.

Pursuant to its monitoring tasks the ESRB may request information from the European System of Central Banks (ESCB), the ESAs, the national supervisory authorities or the national statistics authorities. If information remains unavailable the ESRB may request it from the Member States. ${ }^{248}$ The request may be of either a general or a specific nature and must be addressed in particular to the Union as a whole or to one or more Member States, or to one or more of the ESAs, or to one or more of the national supervisory authorities.

When the ESRB identifies significant risks to financial stability it must provide warnings and, where appropriate, issue recommendations for remedial action. ${ }^{249}$ Warnings and recommendation may be of a general or a specific nature and must be addressed in particular to the Union as a whole or to one or more Member States, or to one or more of the ESAs, or to one or more of the national supervisory authorities. $^{250}$ As the ESRB has no formal legal powers its warnings and recommendations are non-binding, but they are subject to a 'comply-or explain' procedure. In consequence, addressees of recommendations have to inform the ESRB and the Council of the actions undertaken in response and must provide adequate justification for any inaction. ${ }^{251} \mathrm{~A}$ warning or recommendation may be made public when two-thirds of the General Board agree to this. ${ }^{252}$

The ESRB does not have legal personality or its own budget. It has a complicated organisational structure consisting of a General Board, a Steering Committee, an Advisory Technical Committee (ATC) and an Advisory Scientific Committee (ASC). The General Board is the principal decision-making body of the ESRB. Of its 67 (!) members, 38 have a voting right. These are the President and Vice-

\footnotetext{
245 ESRB Regulation, Art. 2 sub (c). In the Regulation 'systemic risk' is defined as 'a risk of disruption in the financial system with the potential to have serious negative consequences for the internal market and the real economy'.

246 De Larosière et al. (2009), p. 38.

247 De Larosière et al. (2009), p. 38.

248 ESRB Regulation, Art. 15(5).

249 ESRB Regulation, Art. 16(1).

250 ESRB Regulation, Art. 16(2).

251 ESRB Regulation, Art. 17(1).

252 ESRB Regulation, Art. 18(1).
} 
President of the ECB, the Governors of the 28 national central banks, a Member of the Commission, the Chairperson of each of the European Supervisory Authorities, the ATC Chair, the ASC Chair and the two ASC Vice-Chairs. The non-voting members consist of one representative per Member State of the competent national supervisory authorities and the President of the Economic and Financial Committee.

Since the ESRB is charged with monitoring systemic risk in the EU's financial system, it would, logically, be best placed to perform our proposed task of designating financial institutions as 'systemically important', in imitation of the FSOC. To this end the ESRB's mandate would need to be expanded, providing the ESRB with the power to adopt legally binding non-bank SIFI designation decisions. The related legal aspects are discussed in Sect. 6.3.1. The ESRB's governance structure would also have to be streamlined as the current number of 38 voting members potentially obstructs and politicises a non-bank SIFI designation decisionmaking process.

\section{Towards Single Supervision of Systemically Important Institutions in the $\mathbf{E U}$}

\subsection{Addressing Systemic Risk: The Institutional Structure}

As discussed in Sect. 2, the global financial crisis revealed the shortcomings of an institutionally organised supervisory model. ${ }^{253}$ Financial institutions falling outside the regulatory perimeter of traditional financial entities may engage in equivalent activities without being subjected to adequate regulation. In the same vein, sectoral supervisors can only monitor the build-up of systemic risk within their competence and thus, by definition, lack a comprehensive overview of the financial sector. The institutional financial supervisory structure in the EU should, therefore, be supplemented by an institution charged with monitoring systemic risk build-up in any financial institution and, when necessary, bring them within an adequate regulatory and supervisory perimeter.

As demonstrated in Sect. 5, an institutional approach is still prevalent in the EU's financial regulatory structure. Because such an approach is especially susceptive to regulatory gaps, it needs to be complemented by a robust monitoring mechanism which has an activity-based approach of detecting systemic risk across the entire financial sector. In the EU, the ESRB provides for monitoring of systemic risks, but lacks substantial formal legal power. The US, in contrast, has equipped the FSOC with substantial systemic risk monitoring powers and the competence to bring systemically important financial institutions within an adequate regulatory and supervisory perimeter, as discussed in Sect. 4. We advocate an expansion of the ESRB's powers, providing it, in imitation of the FSOC, with the competence to designate financial institutions as systemically important and, in consequence, bring them within prudential supervision or enhanced supervision.

253 See also Awrey (2016) pp. 84-86. 
Given the dual legal orders of the EU and its Member States, we would also argue that prudential supervision should be performed at the EU level by an EU institution. As systemically important financial institutions operate across national borders, regulation and supervision should not be confined within such borders. This brings to mind what Dirk Schoenmaker has called the 'financial trilemma': increased financial integration due to globalisation and, more specifically, to the creation of an European internal market is not compatible with both financial stability and national financial policies. ${ }^{254}$ National supervision of non-bank SIFIs has proved inadequate. ${ }^{255}$ This is in part due to inherent jurisdictional limitations and the corresponding fragmentised view of the supervised institution. ${ }^{256}$ Moreover, national authorities might be tempted to practise forbearance in regard to financial institutions perceived as national champions. ${ }^{257}$

Similarly, the resolution of non-bank SIFIs can best be achieved by a Union institution. Much the same arguments as for European supervision apply. Lacking a comprehensive view of a non-bank SIFI's business causes suboptimal resolution decisions. Moreover, national authorities have strong incentives to minimise the impact of failing non-bank SIFIs on their economy. ${ }^{258}$ This can result in unilateral measures such as requiring higher capital and liquidity buffers or limiting intragroup transfers. Maintaining financial stability is not the prime aim of such measures. Consequently, they have the potential to cause unnecessary destruction of the non-bank SIFI's value and distort the functioning of the internal market.

\subsection{Monitoring Systemic Risk}

The global financial crisis exposed the integrated nature, both cross-sectoral and cross-border, of financial markets and institutions. This warrants an integrated approach to the monitoring of financial risks. In the EU the ESRB is tasked with systemic risk monitoring. The ESRB's powers, however, are limited to monitoring and assessing systemic risks and, where appropriate, issuing warnings and recommendations. It does not have formal powers and instead has to rely on systemic risk warnings and non-binding recommendations to EU members, which can be punctuated by a 'comply or explain' mechanism.

\footnotetext{
254 Schoenmaker (2013).

255 In consequence, the de Larosière report found that Europe should be equipped with a standard set of rules and that strengthened international collaboration in the supervision of large complex cross-border financial groups is of crucial importance. See De Larosière et al. (2009).

256 The Commission, for instance, notes in its consultation on the reform of the European Supervisory Agencies that stakeholders confirmed that the understanding and supervision of investment funds is very different among National Competent Authorities, which ultimately limits the uptake of these funds. See European Commission (2017), p. 17. Similarly, recital (5) of the SSM Regulation grants that the creation of the SSM was prompted by the conviction that 'Coordination between supervisors is vital, but the crisis has shown that mere coordination is not enough, in particular in the context of a single currency. In order to preserve financial stability in the Union and increase the positive effects of market integration on growth and welfare, integration of supervisory responsibilities should therefore be enhanced'. This holds similarly true for the supervision of non-bank SIFIs.

257 Véron (2013)

258 This is also cited as a basis for the creation of the SRM. See recital (9), SRM Regulation.
} 
In regard to the collection of information, it is of interest to note that the ESRB may request information of the ESA's, the ECB, the Commission and national supervisors, statistics authorities and member states. ${ }^{259}$ However, as the information provided has to be in aggregate form, it is impossible to distinguish individual firms. If, as we propose below, the ESRB is to be able to make non-bank SIFI designations comparable to the FSOC designations, this limitation has to be removed.

In the US, the FSOC is charged with identifying risks to the financial stability of the United States, promoting market discipline, and responding to emerging risks to the stability of the US financial system. Its powers include the designation of nonbank financial institutions and financial market utilities to be supervised by the Federal Reserve Board. It may issue recommendations on heightened prudential standards to supervisory authorities. Moreover, it makes recommendations on jurisdictional disputes and reports on regulatory gaps to Congress.

\subsection{Non-bank SIFI Designation}

We propose that the ESRB be equipped with powers similar to those of the FSOC to designate non-bank financial companies as systemically important and, consequently, deserving of additional prudential regulation and supervision. This would go a long way towards alleviating systemic risks by creating a mechanism to ensure non-bank SIFIs are subjected to a regulatory perimeter consistent with the risks they pose. Such a designation would be an important instrument in preventing regulatory arbitrage. Indeed, echoing the designation process of the FSOC, we would note that the level of regulatory scrutiny to which a non-bank SIFI is subjected is an important factor when deciding on a designation.

\subsubsection{Legal Feasibility}

The ESRB could be given the power to designate non-bank SIFIs under Article 114 TFEU, as it aims to improve the functioning of the internal market by helping to provide financial stability. Indeed, the very goal of such a designation is to make sure that such non-bank SIFIs are regulated to an extent consistent with the level of systemic risk they pose. Consequently, the power to make such a designation is conditional on whether it addresses a threat to financial stability and whether such a designation would alleviate the threat.

However, such a power of designation for the ESRB might be subject to legal constraints on the delegation of discretionary powers to agencies. The EU Member States have delegated powers to the EU through the Treaties. In turn, the Union legislature may decide to delegate some of these powers to an agency in cases where the Treaties provide for this possibility either in a specific provision or in the form of a general competence such as Article 114 TFEU.

\footnotetext{
259 The European Commission, in its consultation document on the Review of the EU Macro-Prudential Framework, provides that the ESRB could benefit from additional own analytical resources, especially in areas where there is less pre-existing knowledge such as systemic risk outside the banking sector. See Commission (2016).
} 
The degree to which such delegation is allowed was addressed by the Court of Justice of the European Union (CJEU) in its Meroni ruling. ${ }^{260}$ The CJEU distinguished between two types of delegation. Whereas purely executive powers may be delegated as their exercise can be reviewed against objective criteria specified by the delegating authority, powers involving a wide margin of discretion in determining economic policy may not be delegated. Such delegation would replace the choices of the delegating authority by those of the delegatee and bring about an actual transfer of responsibility. ${ }^{261}$ As a transfer of responsibility of this kind would alter the balance of power between the EU institutions, it would be incompatible with the Treaties. ${ }^{262}$

In its Short Selling judgment ${ }^{263}$ the CJEU revisited and revised its Meroni doctrine. First, the CJEU emphasised that the contested delegation in Meroni concerned delegation to an entity governed by private law, whereas the contested delegation in the Short Selling case was to ESMA, which had been established pursuant to an EU regulation. The Court went on to note that ESMA's power to prohibit or impose conditions on the entry by natural or legal persons into a short sale or require them to notify a competent authority or to disclose to the public details of net short positions ${ }^{264}$ does not confer any autonomous power that goes beyond the boundaries of the regulatory framework established by the ESMA Regulation. $^{265}$ Furthermore, and unlike the circumstances in Meroni, ESMA's discretionary powers in regard to short selling are circumscribed by various conditions and criteria. ${ }^{266}$ The CJEU therefore held that the powers available to

\footnotetext{
${ }^{260}$ Case 9-56, Meroni \& Co., Industrie Metallurgiche, SpA v. High Authority of the European Coal and Steel Community, ECLI:EU:C:1958:7 (Meroni).

261 Meroni, p. 152.

262 Ibid.

263 Case C-270/12, The United Kingdom of Great Britain and Northern Ireland v. European Parliament and the Council of the European Union, ECLI:EU:C:2014:18 (Short Selling).

264 As provided for under Art. 28 of the Short Selling Regulation. See Regulation (EU) No. 236/2012 of the European Parliament and of the Council of 14 March 2012 on short selling and certain aspects of credit default swaps [2012] OJ L86.
}

265 Short Selling, paras. 43-44.

266 Short Selling, paras. 45 and 53. These conditions and criteria require that short selling measures (i) address a threat to the orderly functioning and integrity of financial markets or to the stability of the whole or part of the financial system in the Union and there are cross-border implications; (ii) no competent national authority may have taken measures addressing the threat or such measures have proven not to address the threat adequately. Furthermore, ESMA has to take into account whether the measure does not create a risk of regulatory arbitrage and does not have a detrimental effect on the efficiency of financial markets, which is disproportionate to the benefits of the measure. Additionally, ESMA's measures may only be of a temporary nature and ESMA is required to review the measure at appropriate intervals, at least every 3 months. ESMA is also required to consult the ESRB and, if necessary, other relevant bodies and must notify the competent national authorities concerned of the measure it proposes to take. The powers of ESMA are further delineated by a delegated act of the Commission specifying criteria and factors to be taken into account in determining in which cases certain adverse events or developments and threats to orderly functioning and integrity of financial markets or to the stability of the whole or part of the financial system, arise. See Short Selling, paras. 46-53. The UK, however, unsuccessfully, argued that ESMA's determination as to whether these criteria are met, entails a very large measure of discretion. Especially, it argued, that the judgement whether there is a 'threat' is itself highly subjective. See: Short Selling, para. 28. 
ESMA in regard to short selling are precisely delineated and amenable to judicial review in the light of the objectives established by the delegating authority. Accordingly, it found that those powers comply with the requirements laid down in Meroni. Consequently, those powers do not imply that ESMA is vested with a 'very large measure of discretion' that is incompatible with the Treaties. ${ }^{267}$

In line with the Short Selling ruling it could be argued that granting the ESRB the power to designate non-bank financial institutions as systemically important is not in breach of the Meroni constraints. Much the same conditions and restraints applicable to ESMA's short selling powers would be applicable to the designation procedure as the ESRB too has to make an assessment of a possible threat to the stability of the whole or part of the financial system. The Commission could provide conditions detailing how such an assessment should be made in a delegated regulation. Judicial review of a designation would also be possible as a designation is of direct and individual concern to the subject institution, opening up proceedings, under Article 263 TFEU, before the CJEU.

At the same time, we concede that in order to have in place a forward-looking system for the monitoring and designation of systemically important institutions, it is vital for the ESRB to have a degree of discretion. As the financial sector is ever evolving, the ESRB should not be subject to extremely detailed conditions limiting its ability to review and determine systemic relevance. As the FSOC too notes in its final rule and interpretive guidance on non-bank SIFI designation, a determination decision cannot be reduced to a formula.

In order to loosen possible Meroni constraints, final determination could be subjected to validation by the Commission (or by non-objection within an appropriate time-frame). As the Commission has a direct basis in the Treaties, it is not subjected to Meroni constraints. Such an arrangement has, for the same reasons, been used in the context of the Single Resolution Mechanism, where resolution decisions by the Single Resolution Board are validated by the Commission. Additionally, in the recent legislative proposal on supervision of CCPs, ESMA may make a request to the Commission that a CCP may be of such systemic importance that it will be able to provide services in the Union only if it establishes itself in the EU. Again, the Commission, officially, makes the final determination.

Alternatively, the ESRB or a newly created institution could be endowed with designation powers in the Treaty. This might be the preferable option as it would provide a strong legal basis, without complicating the governance structure by including the Commission. However, as it would require a Treaty change it seems politically unfeasible. On the other hand, political realities could turn out to fluctuate more than the financial markets.

\subsection{Non-bank SIFI Supervision}

As described earlier, new prudential regulation in the US rearranged and expanded financial regulation, supervision and resolution. FSOC-designated 'systemically

267 Short Selling, paras. 53 and 54. 
important' financial institutions are subject to the prudential regulations set out in Title I of the Act and are supervised by the Board of Governors of the Federal Reserve System (FRB). The latter has the discretion to impose additional, tailormade prudential standards and disclosure requirements.

Following the example set by the FSOC, a designation by the ESRB should have the consequence of pulling a financial institution within an appropriate prudential regulatory perimeter and related supervision. This is not to say that a one-size-fitsall approach should be taken in determining prudential requirements. Instead, regulators should have the discretion to set specific requirements reflecting the specific business of a regulated entity. Following the example set by Dodd-Frank, ${ }^{268}$ this should include requirements in relation to capital, leverage limits, liquidity, risk management, resolution planning and credit exposure reporting. Again, following the US model, the prudential standards should be tailored, on an individual basis or by category, to the designated institution. Such standards should reflect the institutions' capital structure, riskiness, complexity, financial activities (including the financial activities of their subsidiaries), size and any other risk-related factors. In consequence, the resulting tailored prudential requirements address the systemic risks while providing a fair regulatory burden, taking into account the specific nature and activities of the institution. ${ }^{269}$

European supervision could be realised by having designated non-bank SIFIs fall within the scope of the Banking Union. In addition to supervising significant eurozone banks, the ECB would then also be charged with supervising of non-bank financial institution designated by the ESRB as systemically important. ${ }^{270}$ In this scenario it would be most sensible to have the ECB determine adequate prudential requirements for the designated institution.

Alternatively, another EU entity could be charged with supervision. A possible connection could be made with the intended or successive reforms of the European Supervisory Agencies, as discussed in Sect. 5.2.2. Pursuant to a non-bank SIFI designation by the ESRB, the ESA which has most affinity with the designate institution would operate as direct prudential supervisor. Direct supervision by an ESA is not unprecedented as ESMA already has direct supervisory tasks. Some would prefer this option as it would remove the perception that designated institutions are regulated and supervised as banks by the ECB. Moreover, as the ECB, arguably, already has a conflict of interest between monetary policy and prudential supervisory objectives, this would be even more the case if it were also to

\footnotetext{
26812 US Code $\$ 5365$.

269 The proposed rules of the FRB regarding capital requirements for supervised institutions significantly engaged in insurance activities in the US, follows a similar approach. See Sect. 4.2.

270 The ECB could in this process profit from experience gained in the course of the Supervisory and Review Evaluation Process, in which the ECB has to ensure that credit institutions have adequate arrangements, strategies, processes and mechanisms as well as capital and liquidity to ensure a sound management and coverage of their risks, including risks institutions may pose to the financial system. See CRD IV, Art. 97.
} 
supervise non-bank SIFIs. ${ }^{271}$ At the same time, the ECB could profit from the resources and experiences gained in the context of the Banking Union and from a comprehensive overview of the financial sector. We will limit ourselves to the more fundamental contention that the prudential supervision of non-bank SIFIs, subject to a determination by the ESRB, should be performed by an EU authority as opposed to a national authority. It is, however, important to note that the scope of ECB supervision in the context of the Banking Union currently coincides with that of the eurozone as no additional Member States have acceded. This is more limited than the scope of the ESAs which operate throughout the EU. We prefer a broader scope.

This touches upon an important, additional benefit of our proposed designation and supervision scheme for systemically important institutions. As Schwarcz and Zaring point out, the benefits of a non-bank SIFI identification and supervisory scheme extend beyond the systemic risk mitigation of the supervised institution. First, the possibility to take over or provide additional supervision of designated firms deters the initial supervisors (if any, of course) of the non-bank institutions from applying lax supervisory standards or neglecting to take proper account of systemic risk. ${ }^{272}$ This dimension is of extra importance in the context of the EU where non-bank financial regulation largely depends on national administration. As stated, national supervisors are not well equipped to address systemic risks in crossborder financial institutions. They are ill-positioned to have a comprehensive overview of the risks present in a cross-border financial institution and are predominantly mandated to address national (stability) concerns. National supervisors might also feel tempted to practise supervisory forbearance by giving national champions a competitive advantage. In such cases, the looming threat of losing supervisory control to an EU authority would provide a strong incentive for national supervisors to redouble their efforts. Moreover, an instruction from EU authorities such as the ERSB itself or other agencies to national supervisors would have even greater impact if non-compliance could lead to a non-bank SIFI designation by the ERSB.

\footnotetext{
271 A conflict of interest could occur, for example, if the ECB were tempted to set interest rates beneficial to ailing banks, thus making improper use of a monetary policy instrument. Conversely the Governing Council might be inclined to include monetary policy interests in determining its approval of supervisory decisions, such as the withdrawal of a credit institution's authorisation. Schoenmaker and Véron, however, found in their review on the functioning of SSM during its first 18 months that supervisory tasks have not been distorted or softened by the ECB's monetary policy objectives. See Schoenmaker and Véron (2016), p. 25.

${ }^{272}$ Schwarcz and Zaring indicate that the threat of designation incentivises primary regulators of non-banks to implement reform aimed at limiting systemic risk and take proper account of changes in financial markets which warrant a change in their regulatory approach. See Schwarcz and Zaring (2016), p. 41.

The probability of different priorities in supervision is also acknowledged, and lies at the basis of, the FRB's proposed capital requirements for institutions significantly engaged in insurance activities. The proposed rules set capital requirements for the consolidated institution focusing inter alia on 'enhancing financial stability, and complement the primary mission of state insurance supervisors, which tends to focus on the protection of policyholders'. See Federal Register, Capital Requirements for Supervised Institutions Significantly Engaged in Insurance Activities, Vol. 81, No. 114, 14 June 2016.
} 
Another benefit of the designation regime is that it compels financial institutions to exercise self-restraint when confronted with the threat of being designated as a non-bank SIFI. Since, as already noted, the existing level of regulatory scrutiny is an important factor for a non-bank SIFI determination, financial institutions which add value through regulatory arbitrage activities might be deterred from engaging in these activities if they knew that this might bring them within the scope of a nonbank SIFI designation. In other words, the possibility of being designated as systemically important curbs the risk appetite of institutions. As shown in Sect. 4.4, these effects are already apparent in the US where General Electric has greatly reduced its risk profile in a successful effort to have its non-bank SIFI status rescinded.

\subsubsection{Legal Feasibility}

The scope of the SSM will have to be expanded in order to bring supervision of designated non-bank SIFIs within the scope of the Banking Union. However, the scope of the SSM is subject to Treaty limitations.

Article 127(6) TFEU grants the Council the power to confer specific tasks upon the ECB concerning policies relating to the prudential supervision of credit institutions and other financial institutions with the exception of insurance undertakings. It follows that although the basic treaty provision allows for a broader scope than merely credit institutions, the SSM does not reflect this. Instead the design of the SSM was determined by the need to break the link between sovereigns and banks, as joined supervision paved the way for the mutualisation of bank bailouts. $^{273}$

The scope of the SSM could therefore be expanded to include other financial institutions, provided they do not qualify as insurance undertakings. It could, perhaps, be argued that the term insurance undertaking should be narrowly defined to exclude institutions that deal in bank-like products, as AIG did when it took large positions in credit default swaps.

However, a more legally satisfying approach, albeit perhaps a politically less feasible one, would be to amend the TFEU. The primary function of such an amendment would be to confer on a European body the power to supervise all nonbank SIFI designated entities. Logically, this would be the same body as is in charge of supervision under the SSM.

Alternatively, a European Supervisory Agency could be tasked with the direct prudential supervision of designated non-bank SIFIs. To this end the EU legislators could adopt a regulation on based on Article 114 TFEU in which they delegate these task to a European agency. Article 114 TFEU provides a suitable legal basis as EU supervision harmonises the supervisory practices and thereby improves the conditions for the establishment and functioning of the internal market. This is also in compliance with the principle of subsidiarity and proportionality since the execution of supervision at the EU level is motivated, precisely because, fragmentised supervision at the national level has proven inadequate. Additionally,

273 Moloney (2014b), p. 1624. 
proportionality is an important element in the determination whether or not to designate a financial institutions as a non-bank SIFI and placing it under direct supervision.

In view of the Short Selling judgement, direct prudential supervision by an EU agency seems legally possible when the execution of supervision is circumscribed by various conditions and criteria which limit the agencies discretion and the possibility of judicial protection against the agency's acts. However, while the ECJ's 'mellowing' of Meroni through the Short Selling case provides a legal window to task supervision of non-bank SIFIs with an EU agency, the associated legal uncertainty is troublesome. Furthermore, the fact that no regulatory powers may be conferred to the agency renders it impossible for the agency to adopt tailored prudential requirements for non-bank SIFIs without approval by an EU institution with a Treaty basis.

\subsection{Non-Bank SIFI Resolution}

A credible resolution regime for non-bank SIFIs is of paramount importance in order to create a credible alternative to publicly funded bailouts and help safeguard financial stability by providing for orderly liquidation and allowing for the continued operation of systemically important business processes. Such a regime subjects non-bank SIFIs to market discipline as it cancels out their Too-Big-To-Fail status and associated implicit guarantees.

The European Banking Union (EBU) provides a resolution regime for banks and, subject to certain conditions, their parent companies if they are a financial holding company or mixed financial holding company. Additionally, 730k investment firms and financial institutions' subsidiaries may also fall within the resolution scope of the EBU. This creates a complicated and opaque resolution regime with some entities within a group falling within the resolution scope and others not. The scope of resolution is governed not by the systemic risk posed by an institution and whether this may be mitigated by placing it under resolution but instead by inflexible and arbitrary legal norms.

This leads to regulatory gaps, regulatory arbitrage, an unlevel playing field and an incomplete toolbox for addressing systemic risk, which may manifest itself in different and to some extent unknown forms. A resolution regime needs to reflect this. Therefore non-bank SIFIs should also qualify for liquidation under a European resolution mechanism. This creates a more flexible, open-ended and forwardlooking approach aimed at preventing the next crisis, not the last one.

Inspiration can, again, be drawn from the resolution regime created by the DoddFrank Act in the US. This regime, known as the Orderly Liquidation Authority (OLA), captures any non-bank financial institution whose failure would seriously impact financial stability in the US.

A possible way of strengthening the European resolution regime and mitigating the systemic risks stemming from non-bank entities would be to widen the scope of the SRM to include all financial institutions that pose systemic risk.

It should be remembered that the legal basis of the SRM is Article 114 TFEU, which provides a basis for the adoption of measures for the approximation of the 
provisions in Member States which have as their object the establishment and functioning of the internal market. According to the European Court of Justice (CJEU), measures under Article 114 TFEU must genuinely have as its object the improvement of the conditions for the establishment and functioning of the internal market. $^{274}$

A centralised European resolution authority aims to ensure a uniform application of resolution rules. This enhances the proper functioning of the internal market, specifically in the field of financial services as it eliminates, national, fragmentised resolution rules and thus improves the level playing field. Additionally, its main objective is to strengthen financial stability in the EU: an essential prerequisite for the functioning of the internal market.

This leads to the conclusion that a resolution scheme for non-bank SIFIs or an expansion of the SRM to include such entities does not need Treaty change. Instead, it can be established in accordance with the ordinary legislative procedure on the basis of Article 114 TFEU.

\section{Conclusions}

The global financial crisis revealed that the migration of financial activities outside the traditional banking sector was accompanied by a huge and unchecked build-up of systemic risk. National and/or sectorally organised regulation and supervision proved insufficient owing to the continued integration and interconnectedness of financial markets, institutions, products and services. Gaps in the coverage of regulation and supervision led to an inconsistent regulatory treatment of equivalent products and/or services. This in turn caused an unlevel playing field and encouraged regulatory arbitrage behaviour, which caused a migration of activities and a build-up of systemic risk in the less regulated or unregulated parts of the financial system.

We propose that equivalent financial products and/or services should be subject to an integrated European regulatory and supervisory approach. Above all, institutions that pose systemic risk should be brought within a regulatory perimeter consistent with the risk they pose to financial stability.

A European body should therefore be in charge of monitoring financial institutions active in the EU, and should identify institutions which pose systemic risk. It should, subsequently, have the discretion to designate a non-bank financial firm as a non-bank SIFI. Such designation would ensure a level of regulatory and supervision consistent with the risks to financial stability posed by a financial institution. Given its current tasks, the European Systemic Risk Board seems best suited for this task.

After an institution has been designated as non-bank SIFI, it comes under European supervision. As such a regime has been created for banks in the form of the European Banking Union, designated non-bank SIFIs should be brought within the perimeter of the EBU. While the Treaties exclude insurance companies, other

\footnotetext{
274 See Case 376/98, Germany v. European Parliament and Council, ECLI:EU:C:2000:544, para. 84.
} 
financial institutions can be brought under supervision of the ECB without the need for Treaty change. The ECB would then be able to supervise and impose enhanced prudential standards on designated non-bank SIFIs. Alternatively, another EU entity could be charged with supervision, for example the relevant ESA.

In keeping with the second pillar of the EBU, a regime should also be in place to ensure that non-bank SIFIs can be resolved without causing systemic risk. This would resolve the Too-Big-To-Fail dilemma and subject the institutions concerned to market discipline. A connection could be made with the EBU's second pillar by expanding the scope of the SRM to include designated non-bank SIFIs. Such an inclusion could be based on Article 114 TFEU, as the alleviation of systemic risk greatly improves the functioning of the internal market.

The development of such a regime could be based on the example of the US, where the Dodd-Frank Act provides for the designation of non-bank SIFIs and their regulation, supervision and possible resolution.

Ensuring that non-bank SIFIs are properly regulated, supervised and, if necessary, resolved would help to eliminate supervisory and regulatory gaps, reduce regulatory arbitrage activities, enhance the level playing field and contribute to the stability of the financial system as a whole.

Open Access This article is distributed under the terms of the Creative Commons Attribution 4.0 International License (http://creativecommons.org/licenses/by/4.0/), which permits unrestricted use, distribution, and reproduction in any medium, provided you give appropriate credit to the original author(s) and the source, provide a link to the Creative Commons license, and indicate if changes were made.

\section{References}

Abad J, D'Errico M, Killeen N, Luz V, Peltonen T, Portes R, Urbano T (2017) Mapping the interconnectedness between EU banks and shadow banking entities. European Systemic Risk Board, Working Paper Series no 40. https://www.eba.europa.eu/documents/10180/1431348/ Mapping+the+interconnectedness+between+EU+banks+and+shadow+banking+entities_paper. pdf. Accessed 5 Feb 2018

ABN AMRO (2015) Prospectus. 10 November 2015

Acharya VV, Gale D, Yorulmazer T (2011) Rollover risk and market freezes. J Financ 66(4):1177-1209

Acharya VV, Schnabl P, Suarez G (2013) Securitization without risk transfer. J Financ Econ 107(3):515-536

Admati A, Hellwig M (2014) The bankers' new clothes: what's wrong with banking and what to do about it. Princeton University Press, Princeton

Adrian T, Ashcraft AB, Cetorelli N (2015) Shadow bank monitoring. In: Berger AN, Molyneux P, Wilson JOS (eds) The Oxford handbook of banking, 2nd edn. Oxford University Press, Oxford, pp 378-407

Alexander K (2015) Capital Markets Union from the perspective of the banking industry and prudential supervision. Law Financ Mark Rev 9(3):191-195

Anabtawi I, Schwarcz SL (2011) Regulating systemic risk: towards an analytical framework. Notre Dame Law Rev 86:1349-1412

Armour J, Awrey D, Davies PL, Enriques L, Gordon JN, Mayer CP, Payne J (2016) Principles of financial regulation. Oxford University Press, Oxford

Avgouleas E, Goodhart C (2015) Critical reflections on bank bail-ins. J Financ Regul 1(1):3-29

Awrey D (2016) Law, financial instability, and the institutional structure of financial regulation. In: Anand A (ed) Systemic risk, institutional design, and the regulation of financial markets. Oxford University Press, Oxford, pp 61-96 
Baker D, McArthur T (2009) The value of the 'too big to fail' big bank subsidy. Center for Economic and Policy Research Issue Brief. http://cepr.net/documents/publications/too-big-to-fail-2009-09.pdf. Accessed 5 Feb 2018

Basel Committee on Banking Supervision (2014) Supervisory framework for measuring and controlling large exposures. https://www.bis.org/publ/bcbs283.pdf. Accessed 5 Feb 2018

Basel Committee on Banking Supervision (2017) Consultative document, Guidelines, identification and management of step-in risk. Bank for International Settlements, Basel. https://www.bis.org/bcbs/ publ/d398.pdf. Accessed 5 Feb 2018

Bengtsson E (2013) Shadow banking and financial stability: European money market funds in the global financial crisis. J Int Money Financ 32:579-594

Bernanke BS (2012) Some reflections on the crisis and the policy response. Paper presented at the conference on 'rethinking finance: perspectives on the crisis' presented by the Russel Sage Foundation and The Century Foundation, New York, 13 April 2012, New York

Blinder AS (2013) After the music stopped: the financial crisis, the response, and the work ahead. Penguin Group, New York

Brewer E, Jagtiani J (2013) How much did banks pay to become too-big-to-fail and to become systemically important? J Financ Serv Res 43(1):1-35

Brunnermeier MK (2009) Deciphering the liquidity and credit crunch 2007-2008. J Econ Perspect 23(1):77-100

Busch D (2017) A Capital Markets Union for a divided Europe. J Financ Regul 3(2):262-279

Busch D (2018) A stronger role for the European Supervisory Authorities in the Eu27. In: Busch D, Ferrarini G, Avgouleas E (eds) Capital Markets Union in Europe. Oxford University Press, Oxford, pp 28-53

Busch D, Ferrarini G (eds) (2015) The European Banking Union. Oxford University Press, Oxford

Busch D, Avgouleas E, Ferrarini G (eds) (2018a) Capital Markets Union in Europe. Oxford University Press, Oxford

Busch D, van Rijn MBJ, Louisse M (2018b) How single is the single resolution mechanism? https:// papers.ssrn.com/sol3/papers.cfm?abstract_id=3135473. Accessed 9 Mar 2018

Carvajal A, Dodd R, Moore M, Nier E, Tower I, Zanforlin L (2009) The perimeter of financial regulation. International Monetary Fund, Staff Position Note, SPN/09/07. http://www.imf.org/external/pubs/ft/ spn/2009/spn0907.pdf. Accessed 5 Feb 2018

Cetorelli N (2014) Hybrid intermediaries. Federal Reserve Bank of New York Staff Reports no 705. https://www.newyorkfed.org/medialibrary/media/research/staff_reports/sr705.pdf. Accessed 5 Feb 2018

Chernenko S, Sunderam A (2014) Frictions in shadow banking: evidence from the lending behavior of money market mutual funds. Rev Financ Stud 27(6):1717-1750

Commission (2016) Consultation document review of the eu macro-prudential policy framework, pp 1-8. http://ec.europa.eu/finance/consultations/2016/macroprudential-framework/docs/consultationdocument_en.pdf. Accessed 5 Feb 2018

Council of the European Union (2008) Presidency Conclusions 15 and 16 October 2008 Brussels. http:// www.consilium.europa.eu/uedocs/cms_data/docs/pressdata/en/ec/103441.pdf. Accessed 5 Feb 2018

de Larosière J, Balcerowicz L, Issing O, Masera R, Carthy CM, Nyberg L, Pérez J, Ruding O (2009) The high-level group on financial supervision in the EU. Report 25 February 2009. Brussels. http://ec. europa.eu/internal_market/finances/docs/de_larosiere_report_en.pdf. Accessed 5 Feb 2018

Deyoung R (2015) Banking in the United States. In: Berger AN, Molyneux P, Wilson JOS (eds) The Oxford handbook of banking, 2nd edn. Oxford University Press, Oxford, pp 825-848

Dizard J (2017) The Trump era of light-touch regulation dawns. Financial Times, 3 July 2017

Doyle N, Hermans L, Molitor PA, Weistroffer C (2016) Shadow banking in the euro area: risks and vulnerabilities in the investment fund sector. European Central Bank Occasional Paper Series no 174. https://www.ecb.europa.eu/pub/pdf/scpops/ecbop174.en. pdf?2cc4d889706adbcb918c06de4e5df144. Accessed 5 Feb 2018

Eichengreen B (2015) Hall of mirrors: the great depression, the great recession, and the uses-and misuses - of history. Oxford University Press, Oxford

ESMA (2016) Opinion-key principles for a European framework on loan origination by funds. ESMA/ 2016/596, 11 April 2016

European Banking Authority (2014) Opinion of the European Banking Authority on matters relating to the perimeter of credit institutions. EBA/Op/2014/12, 27 November 2014 
European Banking Authority (2015) Consultation paper-draft EBA guidelines on limits on exposures to shadow banking entities. EBA/CP/2015/06, 19 March 2015

European Banking Authority (2016) Guidelines on limits on exposures to shadow banking entities. EBA/ GL/2015/20, 3 June 2016

European Commission (2013) Shadow banking-addressing new sources of risk in the financial sector. Communication from the Commission to the Council and the European Parliament. COM(2013) 614 final

European Commission (2014) A reformed financial sector for Europe. Communication from the European Commission to the European Parliament, the Council, the European Economic and Social Committee and the Committee of the Regions. COM/2014/0279 final

European Commission (2015a) Action plan on building a capital markets union. COM(2015) 468 final European Commission (2015b) Building a capital markets union. Green paper. COM(2015) 63 final

European Commission (2017) Public consultation on the operations of the European Supervisory Authorities. Brussels, 21 March 2017

European Parliament (2012) Resolution of 20 November 2012 with recommendations to the Commission on the report of 'Towards a genuine Economic and Monetary Union' (2012/2151 INI), Strasbourg, 20 November 2012

European Systemic Risk Board (2016a) EU Shadow Banking Monitor. No 1/July 2016. https://www.esrb. europa.eu/pub/pdf/reports/20160727_shadow_banking_report.en.pdf. Accessed 5 February 2018

European Systemic Risk Board (2016b) Macroprudential policy beyond banking: an ESRB strategy paper. July 2016. https://www.esrb.europa.eu/pub/pdf/reports/20160718_strategy_paper_beyond_ banking.en.pdf. Accessed 5 February

European Systemic Risk Board (2017) EU Shadow Banking Monitor. No 2/May 2017. https://www.esrb. europa.eu/pub/pdf/reports/20170529_shadow_banking_report.en.pdf. Accessed 5 February 2018

Everson M (2015) Regulating the Insurance Sector. In: Moloney N, Ferran E, Payne J (eds) The Oxford handbook of financial regulation. Oxford University Press, Oxford, pp 409-452

Federal Deposit Insurance Corporation (2011a) The orderly liquidation of Lehman Brothers Holdings Inc. under the Dodd-Frank Act. FDIC Q 5(2):1-19

Federal Deposit Insurance Corporation (2011b) Resolution plans required. Fed Reg 76(211):67323

Federal Deposit Insurance Corporation (2013) Resolution of systemically important financial institutions: the single point of entry strategy. Fed Reg 78(243):76614

Federal Reserve System (2008) Financial Holding Company Project. 25 January 2008

Federal Reserve System (2016) Capital requirements for supervised institutions significantly engaged in insurance activities. Fed Reg 81(114):38631

Ferran E (2015) Institutional design: the choices for national systems. In: Moloney N, Ferran E, Payne J (eds) The Oxford handbook of financial regulation. Oxford University Press, Oxford, pp 97-128

Ferran E, Babis VS (2013) The European Single Supervisory Mechanism. University of Cambridge Faculty of Law Legal Studies Research Paper Series, no 10

Financial Crisis Inquiry Commission (2011) The financial crisis inquiry report: final report of the National Commission on the Causes of the Financial and Economic Crisis in the United States. https://www. gpo.gov/fdsys/pkg/GPO-FCIC/pdf/GPO-FCIC.pdf. Accessed 5 Feb 2018

Financial Stability Board (2010a) Intensity and effectiveness of SIFI supervision: recommendations for enhanced supervision. 2 November 2010. https:/www.imf.org/external/np/mcm/financialstability/ papers/sifisup.pdf. Accessed 5 Feb 2018

Financial Stability Board (2010b) Reducing the moral hazard posed by systemically important financial institutions: FSB recommendations and time lines. 20 October 2010. http://www.fsb.org/wp-content/ uploads/r_101111a.pdf?page_moved=1. Accessed 5 Feb 2018

Financial Stability Board (2011a) Key attributes of effective resolution regimes for financial institutions. http://www.fsb.org/wp-content/uploads/r_111104cc.pdf. Accessed 5 Feb 2018

Financial Stability Board (2011b) Policy measures to address systemically important financial institutions. http://www.fsb.org/wp-content/uploads/r_111104bb.pdf?page_moved=1. Accessed 5 Feb 2018

Financial Stability Board (2011c) Shadow banking: strengthening oversight and regulation recommendations of the Financial Stability Board. http://www.fsb.org/wp-content/uploads/r_111027a. pdf?page_moved=1. Accessed 5 Feb 2018

Financial Stability Board (2013a) Overview of progress in the implementation of the G20 recommendations for strengthening financial stability. Report of the Financial Stability Board to G20 Leaders. http://www.fsb.org/wp-content/uploads/r_130905c.pdf?page_moved=1. Accessed 5 Feb 2018 
Financial Stability Board (2013b) Policy framework for strengthening oversight and regulation of shadow banking entities. http://www.fsb.org/wp-content/uploads/r_130829c.pdf. Accessed 5 Feb 2018

Financial Stability Board (2013c) Progress and next steps towards ending 'too-big-to-fail' (TBTF). Report of the Financial Stability Board to the G-20. http://www.fsb.org/wp-content/uploads/r 130902.pdf?page_moved=1. Accessed 5 Feby 2018

Financial Stability Board (2015a) Consultative document (2nd) Assessment methodologies for identifying non-bank non-insurer global systemically important financial institutions: proposed high-level framework and specific methodologies. http://www.fsb.org/wp-content/uploads/2nd-Con-Doc-onNBNI-G-SIFI-methodologies.pdf. Accessed 5 Feb 2018

Financial Stability Board (2015b) Global shadow banking monitoring report 2015. http://www.fsb.org/ wp-content/uploads/global-shadow-banking-monitoring-report-2015.pdf. Accessed 5 Feb 2018

Financial Stability Board (2015c) Transforming shadow banking into resilient market-based finance: an overview of progress. http://www.fsb.org/wp-content/uploads/shadow_banking_overview_of_ progress_2015.pdf. Accessed 5 Feb 2018

Financial Stability Board (2016) Thematic review on the implementation of the FSB policy framework for shadow banking entities. http://www.fsb.org/wp-content/uploads/Shadow-banking-peer-review. pdf. Accessed 5 Feb 2018

Financial Stability Board (2017a) Assessment of shadow banking activities, risks and the adequacy of post-crisis policy tools to address financial stability concerns. http://www.fsb.org/wp-content/ uploads/P300617-1.pdf. Accessed 5 Feb 2018

Financial Stability Board (2017b) Global shadow banking monitoring report 2016. http://www.fsb.org/ wp-content/uploads/global-shadow-banking-monitoring-report-2016.pdf. Accessed 5 Feb 2018

Financial Stability Board (2017c) Policy recommendations to address structural vulnerabilities from asset management activities. http://www.fsb.org/wp-content/uploads/FSB-Policy-Recommendations-onAsset-Management-Structural-Vulnerabilities.pdf. Accessed 5 Feb 2018

Financial Stability Oversight Council (2012) Authority to require supervision and regulation of certain nonbank financial companies. Fed Reg 77(70):21637

Financial Stability Oversight Council (2016) Basis for the financial stability oversight council's rescission of its determination regarding GE Capital Global Holdings, LLC. https:/www.treasury.gov/ initiatives/fsoc/designations/Documents/GE\%20Capital\%20Public\%20Rescission\%20Basis.pdf. Accessed 5 Feb 2018

Fleming MJ, Sarkar A (2014) The failure resolution of Lehman Brothers. FRBNY Econ Policy Rev 20(2):175-206

French KR, Baily MN, Campbell JY, Cochrane JH, Diamond DW, Duffie D, Kashyap AK, Mishkin FS, Rajan RG, Scharfstein DS (2010) The Squam Lake report: fixing the financial system. Princeton University Press, Princeton

G20 (2009a) G20 Leaders Statement: global plan for recovery and reform. London. https://www.g20.org/ profiles/g20/modules/custom/g20_beverly/img/timeline/ReinoUnido/G20-declaration-london-en. pdf. Accessed 5 Feb 2018

G20 (2009b) G20 Leaders Statement: the Pittsburgh Summit. Pittsburgh. https:/www.g20.org/profiles/ g20/modules/custom/g20_beverly/img/timeline/Pittsburgh/G20-declaration-pittsburgh-2009-en.pdf. Accessed 5 Feb 2018

Goodley S, Treanor J (2016) Property funds halt trading as Brexit fallout deepens. The Guardian, 5 July 2016

Gorton G, Metrick A (2012) Securitized banking and the run on repo. J Financ Econ 104(3):425-451

Gros D, Micossi S (2008) European banking on borrowed time. Financial Times, 23 September 2008

Gruenberg MJ (2015) A progress report on the resolution of systemically important financial institutions. Washington, DC. https://www.fdic.gov/news/news/speeches/spmay1215.pdf. Accessed 5 Feb 2018

Huang RH, Schoenmaker D (eds) (2014) Institutional structure of financial regulation: theories and international experiences. Routledge, Abingdon

Juncker J-C, Tusk D, Dijsselbloem J, Draghi M, Schulz M (2015) Completing Europe's economic and monetary union. Five Presidents' Report. https://www.ecb.europa.eu/pub/pdf/other/ 5presidentsreport.en.pdf. Accessed 5 Feb 2018

Kacperczyk M, Schnabl P (2013) How safe are money market funds? Q J Econ 128(3):1073-1122

Labaton S (2008) S.E.C. concedes oversight flaws fueled collapse. The New York Times, 26 September 2008

Lane PR (2012) The European sovereign debt crisis. J Econ Perspect 26(3):49-67 
Lastra RM (2015) Systemic risk \& macro-prudential supervision. In: Moloney N, Ferran E, Payne J (eds) The Oxford handbook of financial regulation. Oxford University Press, Oxford, pp 309-333

Lew JJ (2016) Why we're reviewing asset management. Wall Street Journal, 19 April 2016

Lowenstein R (2000) When genius failed: the rise and fall of long-term capital management. Harpercollins Publishers, New York

McCabe PE, Cipriani M, Holscher M, Martin A (2012) The minimum balance at risk: a proposal to mitigate the systemic risks posed by money market funds. Federal Reserve Bank of New York Staff Reports no 564. https://www.newyorkfed.org/medialibrary/media/research/staff_reports/sr564.pdf. Accessed 5 Feb 2018

Merler S, Pisani-Ferry J (2012) Who's afraid of sovereign bonds? Bruegel Policy Contribution. http:// bruegel.org/wp-content/uploads/imported/publications/pc_2012_02_debt_.pdf. Accessed 5 Feb 2018

Moloney N (2014a) EU securities and financial markets regulation. Oxford University Press, Oxford

Moloney N (2014b) European Banking Union: assessing its risks and resilience. Common Mark Law Rev 51(6):1609-1670

Moore MJ, Onaran Y, Comfort N (2015) Biggest global banks shrink under pressure from regulators. Bloomberg, 27 February 2015

Pacces AM, Nabilou H (2017) The law and economics of shadow banking. European Corporate Governance Institute Law Working Paper no 339. http://www.ecgi.global/sites/default/files/ working_papers/documents/ssrn-id28843742.pdf. Accessed 5 Feb 2018

Pisani-Ferry J (2012) The euro crisis and the new impossible trinity. Bruegel Policy Contribution. http:// bruegel.org/wp-content/uploads/imported/publications/pc_2012_01_.pdf. Accessed 5 Feb 2018

Posen A, Véron N (2014) Europe's half a banking union. http://bruegel.org/2014/09/europes-half-abanking-union/. Accessed 17 July 2017

Pozsar Z, Adrian T, Ashcraft AB, Boesky H (2010) Shadow banking. Federal Reserve Bank of New York Staff Reports no 458. https://www.newyorkfed.org/medialibrary/media/research/staff_reports/sr458. pdf. Accessed 5 Feb 2018

Rajan R (2011) Fault lines: how hidden fractures still threaten the world economy, 10th edn. Princeton University Press, Princeton

Santos JAC (2014) Evidence from the bond market on banks' 'too-big-to-fail' subsidy. Econ Policy Rev 20(2):29-39

Schillig M (2016) Resolution and insolvency of banks and financial institutions. Oxford University Press, Oxford

Schoenmaker D (2013) Governance of international banking: the financial trilemma. Oxford University Press, Oxford

Schoenmaker D, Véron N (eds) (2016) European banking supervision: the first eighteen months, vol 25. Bruegel Blueprint Series, Brussels. http://bruegel.org/wp-content/uploads/2016/06/Blueprint-XXVweb.pdf. Accessed 5 Feb 2018

Schwarcz SL (2008) Systemic risk. Georgetown Law J 97:193-249

Schwarcz SL (2011) Regulating shadow banking: inaugural address for the inaugural symposium of the Review of Banking and Financial Law. Rev Bank Financ Law 31(2):619-642

Schwarcz D, Schwarcz SL (2014) Regulating systemic risk in insurance. Univ Chic Law Rev 81(4):1569-1640

Schwarcz D, Zaring DT (2016) Regulation by threat: understanding Dodd-Frank's regulation of systemically significant non-bank financial companies (preliminary version). https://www.law.ox.ac. uk/sites/files/oxlaw/regulation_by_threat_nov_6_-_zaring.pdf. Accessed 5 Feb 2018

Scott HS (2010) Reducing systemic risk through the reform of capital regulation. J Int Econ Law 13(3):763-778

Scott HS (2016) Connectedness and contagion: protecting the financial system from panics. MIT Press, Cambridge

Sender H (2009) AIG still faces billions in credit losses. Financial Times, 4 March 2009

van Setten L, Busch D (eds) (2014) Alternative investment funds in Europe. Oxford University Press, Oxford

Véron N (2013) Banking nationalism and the European crisis. Remarks before a symposium of the European Private Equity and Venture Capital Association, Istanbul, 27 June 2013

Véron N (2015) Europe's radical Banking Union. Bruegel Essay and Lecture Series. http://bruegel.org/ wp-content/uploads/imported/publications/essay_NV_CMU.pdf. Accessed 5 Feb 2018 
Véron N, Wolff GB (2016) Capital Markets Union: a vision for the long term. J Financ Regul 2(1):139-153

Wan JS (2016) Systemically important asset managers: perspectives on Dodd-Frank's systemic designation mechanism. Columbia Law Rev 113(3):805-841

Wolf M (2014) The Shifts and the Shocks: what we've learned-and have still to learn-from the financial crisis. Penguin, London

Wymeersch E (2014) The Single Supervisory Mechanism or 'SSM', part one of the Banking Union. National Bank of Belgium Working Paper no 255. https://papers.ssrn.com/sol3/papers.cfm?abstract_ $\mathrm{id}=2427577$. Accessed 5 Feb 2018

Zetzsche D (ed) (2015) The alternative investment fund managers directive, 2nd edn. Kluwer Law International, Alphen aan den Rijn 